Columbia Law School

Scholarship Archive

2012

\title{
The Political Economy of Dodd-Frank: Why Financial Reform Tends to be Frustrated and Systemic Risk Perpetuated
}

John C. Coffee Jr.

Columbia Law School, jcoffee@law.columbia.edu

Follow this and additional works at: https://scholarship.law.columbia.edu/faculty_scholarship

Part of the Banking and Finance Law Commons, Law and Economics Commons, and the Securities Law Commons

\section{Recommended Citation}

John C. Coffee Jr., The Political Economy of Dodd-Frank: Why Financial Reform Tends to be Frustrated and Systemic Risk Perpetuated, 97 CORNELL L. REV. 1019 (2012).

Available at: https://scholarship.law.columbia.edu/faculty_scholarship/517

This Article is brought to you for free and open access by the Faculty Publications at Scholarship Archive. It has been accepted for inclusion in Faculty Scholarship by an authorized administrator of Scholarship Archive. For more information, please contact scholarshiparchive@law.columbia.edu. 


\title{
THE POLITICAL ECONOMY OF DODD-FRANK: WHY FINANCIAL REFORM TENDS TO BE FRUSTRATED AND SYSTEMIC RISK PERPETUATED
}

\author{
John C. Coffee, Jr.†
}

INTRODUCTION ..................................... 1020

I. The Regulatory Sine Curve and Statutory

Correction .................................. 1029

II. SOX Revisited: The Downsizing of Reform .......... 1037

A. Section 404 and Internal Control Reports ......... 1037

B. Executive Loans and Section $402 \ldots \ldots \ldots \ldots \ldots . \ldots 1041$

C. Attorneys as Whistle Blowers and Section 307 ..... 1043

D. An Evaluation ............................ 1046

III. The Dodd-Frank Act: Premises and Policy Options... 1047

A. Moral Hazard: "Executive Compensation Caused the Crash" ................................. 1047

B. Because Creditors Believed That "Too Big to Fail" (TBTF) Banks Would Always Be Bailed Out, They Advanced Funds Too Cheaply and Encouraged Banks to Become Overleveraged ................ 1048

C. Bounded Rationality: Cognitive Limitations, Conflicts of Interest, and a Lack of Transparency Induced Market Participants to Repress Recognition of the Problems Overtaking the Market........... 1048

1. Executive Compensation and Shareholder Pressure.... 1051

2. Systemic Risk and the "Too Big to Fail" Problem ..... 1056

a. Higher Equity Capital Requirements ........... 1058

b. A Private, Industry-Funded Insurance System . . . 1058

c. Reducing Risk Through Prophylactic Rules..... 1058

D. The Over-the-Counter (OTC) Derivatives Market ... 1062

IV. The Implementation of THE Dodd-Frank Act ........ 1065

A. Curbing Executive Compensation: The Road Not

Taken ............................... 1065

1. Proxy Access and Corporate Governance.......... 1065

$\uparrow$ Adolf A. Berle Professor of Law, Columbia University Law School. The author wishes to thank his colleague Professor Robert Jackson for assistance and also acknowledge helpful comments from Lucian Bebchuk and the participants at the Cornell Law Review and Clarke Business Law Institute Symposium: Financial Regulatory Reform in the Wake of the Dodd-Frank Act. 


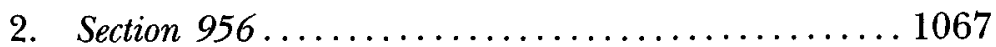

B. The TBTF Problem..................... 1072

1. Resolution Authority ...................... 1073

2. The Volcker Rule ........................ 1073

3. Contingent Capital ...................... 1075

C. The Legislative Counterattack ............... 1076

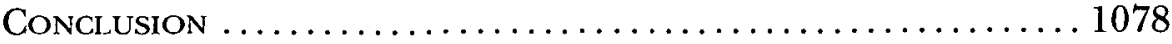

\section{INTRODUCTION}

A good crisis should never go to waste. In the world of financial regulation, experience has shown-since at least the time of the South Sea Bubble three hundred years ago-that only after a catastrophic market collapse can legislators and regulators overcome the resistance of the financial community and adopt comprehensive "reform" legislation. ${ }^{1}$ U.S. financial history both confirms and conforms to this generalization. The Securities Act of 1933 and the Securities Exchange Act of 1934 were the product of the 1929 stock-market crash and the Great Depression, with their enactment following the inauguration of President Franklin Roosevelt in 1933. The 1932 to 1934 Pecora Hearings before the Senate Banking and Currency Committee fueled public indignation and shaped these statutes. ${ }^{2}$ Following the collapse of Enron in late 2001, WorldCom in 2002, and an accelerating crescendo of financial statement restatements by other public corporations, Congress enacted, possibly in some haste, the Sarbanes-Oxley Act (SOX). ${ }^{3}$ The Dodd-Frank Act, enacted in $2010,{ }^{4}$ followed an even greater financial collapse, one that threatened financial institutions on a global scale and brought the problem of systemic risk to the attention of a public already infuriated at financial institutions (and their highly compensated investment bankers) being bailed out at taxpayer expense. Both of these episodes revealed abundant evidence of financial chicanery and fraud that outraged and repulsed the public. ${ }^{5}$ Not surprisingly, the comprehensive reform legislation that followed in the wake of the market collapse showed

1 For the view that, over the last 300 years, securities regulation has depended on market crashes to fuel its expansion, see Stuart Banner, What Causes New Securities Regulation? 300 Years of Evidence, 75 WASH. U. L.Q. 849, 849-51 (1997).

2 See Joel Seligman, The Transformation of Wall Street: A History of the Securities and Exchange Commission and Modern Corporate Finance 1-2, 39-40 (1982).

3 For a description of the increasing rate of financial irregularity and accounting restatements in this era leading up to the enactment of SOX, see John C. Coffee, Jr., What Caused Enron? A Capsule Social and Economic History of the 1990s, 89 CoRnell L. REv. 269, 281-86 (2004).

4 Dodd-Frank Wall Street Reform and Consumer Protection Act (Dodd-Frank Act), Pub. L. No. 111-203, 124 Stat. 1376 (2010).

5 See, e.g., Gary Strauss, How Did Business Get So Darn Dirty?, USA Today, June 12, 2002, at $1 B$ (noting public anger at the financial crises of 2001-2002); Jeff Zeleny, As the 
hints of the public's desire for retribution. ${ }^{6}$ All that differs this time is that the crisis may be wasted-as hereinafter explained.

Why is it that Congress seems to only pass securities and financial reform legislation after a crash or similar crisis? The most plausible answer involves a basic and foundational theory of political science. While in the United States investors and shareholders are numerous, they are also dispersed, disorganized, and their potential political power is diffused. Easily distracted by other important issues, investors' and shareholders' attention span is short. In contrast, the financial services industry is well organized, focuses on the issues that most affect it, and has an obvious incentive to maintain a powerful lobbying presence that will give the industry disproportionate influence. Hence, as any reader of Mancur Olson's classic book, The Logic of Collective Action, ${ }^{7}$ will recognize, smaller, better-organized groups are likely to dominate larger, more diffuse groups in seeking to influence either legislation or regulatory policy. ${ }^{8}$ Olson's prediction that smaller, cohesive interest groups would predictably outperform larger, citizen-based "latent" groups seems obvious, but implies that groups representing investors or shareholders are likely to be at a severe disadvantage in competing with well-funded business lobbies.

If so, how is it then that reform legislation ever passes? Later theorists, building on Olson's model, focused on the role of "political entrepreneurs." In crises, including market crashes, political entre-

Public Simmers, Obama Lets Off Steam, N.Y. Times, Mar. 21, 2009, at A10 (describing "the searing outrage over bonuses paid by companies being kept afloat" with public funds).

6 In the case of SOX, this is clearest in the new criminal penalties and enhanced penalties in Sections 902 to 906. Sarbanes-Oxley Act of 2002, Pub. L. No. 107-204, $\$ \$ 902-06,116$ Stat. 745, 805-06 (codified in scattered sections of 18 and 28 U.S.C. (2006)). In the case of the Dodd-Frank Act, Section 748 sets forth elaborate provisions to protect and subsidize "whistle blowers" who report misconduct to the SEC. Dodd-Frank Act $\S 748$. Both Sections $902-06$ of SOX and Section 748 of the Dodd-Frank Act seek to detect and punish miscreants.

7 See Mancur Olson, The logic of Collective Action: Public Goods and the Theory of Groups 33-36 (2d ed. 1971).

8 For later and fuller statements of Olson's seminal "public choice" perspective, see Russell Hardin, Collective Action 20-22 (1982) and Todd Sandler, Collective AcTiOn: Theory and Applications 3-7 (1992). For an application of Olson's ideas to the world of corporate governance, see Robert A. Prentice \& David B. Spence, Sarbanes-Oxley as Quack Corporate Governance: How Wise is the Received Wisdom?, 95 GEO. L.J. 1843, 1847-49 (2007).

9 The "political entrepreneur" or "public entrepreneur" is a creative actor, modeled after Joseph Schumpeter's economic entrepreneur, who solves the essential dilemma in Mancur Olson's theory of collective action: that individuals would rationally prefer to free ride on the efforts of others. See OLSON, supra note 7, at 33-35. See generally Elinor Ostrom, Public Entrepreneurship: A Case Study in Ground Water Basin Management (Sept. 29, 1964) (unpublished Ph.D. dissertation, University of California Los Angeles), available at http://dlc.dlib.indiana.edu/dlc/bitstream/handle/10535/3581/eostr001.pdf (introducing the concept of a public entrepreneur). Olson was extremely pessimistic about the ability of large groups to take meaningful action. See OLson, supra note 7, at 33-36. Later 
preneurs gain attention and electoral success by exploiting the popular discontent. ${ }^{10}$ These entrepreneurs assume the transaction costs of organizing otherwise latent interest groups in order to secure election, or re-election, by assisting the public to overcome entrenched business interests. ${ }^{11}$

For many, this is precisely how republican government ought to function: leaders rise to aggregate the discontent and frustrations of citizens. ${ }^{12}$ But to a vocal school of academic critics, such democratic eruptions are dismaying, dangerous, and need to be discouraged. The most outspoken and doctrinaire of these critics is undoubtedly Yale Law School Professor Roberta Romano. In a well-known article, Professor Romano condemned SOX for imposing "quack corporate governance" on the United States. ${ }^{13}$ Her thesis is, narrowly, that available empirical academic literature did not support SOX's key corporate-governance provisions and, more generally, that when Congress

theorists explain reform legislation as the product of political entrepreneurs seeking "political profit" in the form of votes or election to office. Richard E. Wagner, Pressure Groups and Political Entrepreneurs: A Review Article, 1 Pub. CHolce 161, 163-65 (1966) (using the term "political profit" in a review of Olson's The Logic of Collective Action); see Stephan Kuhnert, An Evolutionary Theory of Collective Action: Schumpeterian Entrepreneurship for the Common Good, 12 Const. Pol. Econ. 13, 15 (2001) (defining "political profit" to mean "democratic votes, specifically a maximized share of votes"). By manipulating incentives and rewarding their coalition partners, these actors motivate otherwise passive latent groups. See Elinor Ostrom, Governing the Commons: The Evolution of Institutions for ColLECTIVE ACTION 41 (1990). To summarize, from the perspective of political science, the political entrepreneur is the dynamic actor who makes collective action in the common interest possible by bearing the transaction costs that group members will not bear. Some political figures played such an entrepreneurial role after both the Enron and WorldCom scandals of 2001 and 2002 and the 2008 financial crisis. Eliot Spitzer and Andrew Cuomo, who each moved from New York Attorney General to New York Governor after achieving broad recognition for actively challenging misconduct and conflicts of interest on Wall Street, are the most obvious nominees for such a role. See, e.g., Jonathan R. Macey, Wall Street in Turmoil: State-Federal Relations Post-Eliot Spitzer, 70 Brook. L. REv. 117, 117 (2004) (calling Spitzer a "[r] egulatory entrepreneur," who "achieve[d] fame and political support by aggressively entering the regulatory vaccum created by the Security and Exchange Commission's failure vigorously to pursue the corporations implicated in the various scandals"). It is unclear whether any corresponding figure, with the possible exception of SEC Chairman Arthur Levitt, has played a functionally similar role on the national level.

10 See Macey, supra note 9.

11 See Hardin, supra note 8, at 35-37 (explaining the role of political entrepreneurs who market ideas and aggregate support from latent groups). Anthony Downs argues persuasively that legislative inertia and interest group veto power can be overcome and reform legislation passed only during periods of intense public pressure for change. See Anthony Downs, Up and Down with Ecology-The "Issue-Attention Cycle," 28 PuB. INT. 38, 39-41 (1972). In the view of several commentators the passage of environmental laws followed this same cycle. See Christopher H. Schroeder, Rational Choice Versus Republican Moment-Explanations for Environmental Laws, 1969-73, 9 Duke ENvTL. L \& Pol'y F. 29, 33-56 (1998).

12 See, e.g., Michael S. Kang, Race and Democratic Contestation, 117 YALE L.J. 734, 755 (2008) (noting that political leaders "help the mass public overcome the usual collective action problems that beset mass coordination").

13 See Roberta Romano, The Sarbanes-Oxley Act and the Making of Quack Corporate Governance, 114 YALE L.J. 1521, 1526-27 (2005). 
acts in the wake of a financial crisis it adopts hasty, ill-conceived legislation. ${ }^{14}$ Thus, she proposes that all congressional legislation regulating the securities markets or corporate governance come with a mandatory sunset provision under which the legislation would expire within a brief period thereafter, unless a subsequent Congress readopted the legislation. ${ }^{15}$

Any such reform ignores Mancur Olson's critical insight: in the long term, smaller, better-motivated interest groups will likely dominate over the majority. ${ }^{16}$ Thus, crisis breeds an opportunity to overcome legislative inertia. From this starting point, it follows that the consequence of a mandatory sunset rule is to protect the hegemony of well-financed and better-organized interest groups from majoritarian attack. After the financial crisis passes and some semblance of "normalcy" returns, potential political entrepreneurs will be less willing to take on a coalition of well-financed, tightly organized business interest groups because they would know that the dispersed investor community cannot maintain its zeal for long. Financial industry lobbyists could then easily organize to prevent the reenactment of the original legislation once it reached its moment of sunset. As a result, passage of significant legislation would mark only the midpoint of the political battle, which would become more protracted and costly, extending to the end of the sunset period and potentially chilling aggressive administrative implementation during the interim.

Under the Romano proposal, reform legislation would automatically lapse unless (1) the SEC first studied and approved these provisions, and (2) Congress reenacted these provisions, based on the

14 See id. at 1526-27, 1591-94 (2005) (asserting that existing empirical studies were "unnoticed or . . . ignored" by legislators who formulated SOX, and making the larger point that "congressional lawmaking in times of perceived emergency offers windows of opportunity to well-positioned policy entrepreneurs ... when there is little time for reflective deliberation").

15 See id. at 1600-02. Professor Romano also criticizes the role of "policy entrepreneurs" in the passage of SOX. See id. at 1568-69. However, she does not use this term in any defined or theoretical sense, but simply levies ad hoc criticisms at a variety of elected and administrative officials, most notably Senator Sarbanes. See id. at 1584 (singling out, without defining, the committee chairman's "critical entrepreneurial role" in SOX's passage). Indeed, Professor Romano most frequently criticizes policy entrepreneurs SEC Chairman Arthur Levitt and SEC Chief Accountant Lynn Turner. See id. at 1549-50. Neither did politicians holding or seeking office stand to gain from political activism; thus, these politicians did not satisfy the public entrepreneur definition used in the political science literature as one seeking political profit. See supra note 9. Rather, these persons come closer to being technocrats on the highest level. Thus, Professor Romano's critique of the individuals most involved in the enactment of SOX never integrates with any broader theory, and she never discusses Mancur Olson or other political science theorists. Her article seems generally unaware of the political science literature and focuses exclusively on empirical economics.

16 See Olson, supra note 7, at 33-36. 
SEC's endorsement, within a few years thereafter. ${ }^{17}$ More recently, Professor Romano refined her procedures, but still insisted on a mandatory sunset after five to six years, not just for securities laws, but also for all "foundational financial legislation." 18 Thus, under her approach, not only would the Securities Act of 1933 and the Securities Exchange Act of 1934 have expired by the end of the 1930s, but similarly, the Glass-Steagall Act or legislation regulating the capital adequacy and risk management polices of banks and other financial institutions would also self-destruct, unless spared by Congress. Such an outcome seems sensible only if one believes, as Professor Romano may, that markets need little regulation and regulatory interventions, if any, should be short-lived, disappearing like snowflakes in the sun.

Nonetheless, Professor Romano has her loyal allies. ${ }^{19}$ Together, they comprise a "Tea Party Caucus" 20 of corporate and securities law professors and their key themes are: (1) Congress should not legislate after a market crash, because the result will be a "Bubble Law" that crudely overregulates; ${ }^{21}$ (2) state laws are superior to federal law in regulating corporate governance because the competitive pressure of

17 See Romano, supra note 13, at 1601. Even with SEC endorsement, Romano contemplates that Congress would still have to reenact the statute. See id.

18 See Roberta Romano, Regulating in the Dark 1 (Yale Law Sch. John M. Olin Ctr. for Studies in Law, Econ., and Pub. Pol'y, Research Paper No. 442, 2011), available at http:// papers.ssrn.com/sol3/papers.cfm?abstract_id=1974148. Under her revised proposal, the sunset would take effect in five to six years. See id. at 15.

19 See Stephen M. Bainbridge, The Complete Guide to Sarbanes-Oxley: Understandinc How Sarbanes-Oxley Affects Your Business 20 (2007); Henry N. Butler \& Larry E. Ribstein, The Sarbanes-Oxley Debacle: What We've Learned; How to Fix It 16-18 (2006); Stephen M. Bainbridge, Sarbanes-Oxley: Legislating in Haste, Repenting in Leisure, 2 Corp. Governance L. Rev. 69, 70 (2006); Larry E. Ribstein, Commentary, Bubble Laws, 40 Hous. L. Rev. 77, 79-82, 87-90 (2003) [hereinafter Ribstein, Bubble Laws]; Larry E. Ribstein, International Implications of Sarbanes-Oxley: Raising the Rent on US Law, $3 \mathrm{~J}$. CoRP. L. STud. 299, 301-05 (2003) [hereinafter Ribstein, International Implications]; Larry E. Ribstein, Market vs. Regulatory Responses to Corporate Fraud: A Critique of the Sarbanes-Oxley Act of 2002, 28 J. CoRP. L. 1, 57-61 (2002) [hereinafter Ribstein, Market vs. Regulatory]; Larry E. Ribstein, Sarbanes-Oxley After Three Years, 2005 N.Z. L. REv. 365, 375-77 (2005) [hereinafter Ribstein, Sarbanes-Oxley]; Larry E. Ribstein, Sarbox: The Road to Nirvana, 2004 MICH. ST. L. Rev. 279, 293-94 (2004) [hereinafter Ribstein, Sarbox].

Although these authors do not tire of criticizing SOX, they have not convinced others. Reviewing the same economic evidence, Professor John C. Coates finds it hard to balance the costs and benefits of SOX and takes a generally more balanced position. John C. Coates, IV, The Goals and Promise of the Sarbanes-Oxley Act, 21 J. Econ. PersP. 91, 91-92 (2007). Viewing SOX in a less economic light, Professor Donald Langevoort sees SOX as reflecting a congressional shift from an exclusively contractarian perspective to a more trust-based conception of the corporation. See Donald C. Langevoort, The Social Construction of Sarbanes-Oxley, 105 MicH. L. REv. 1817, 1828-33 (2007).

20 While there is irony in this term, it is also intended to be accurate; the three occupy a polar position at one end of the continuum in terms of their unbroken skepticism and rejection of governmental regulation. At the same time, all three are original and creative legal scholars.

21 Both Professors Bainbridge and Ribstein regularly use the term "Bubble Law" to refer to federal iegislation adopted in the wake of a crash that tends to displace state corpo- 
the market for corporate charters desirably restrains activism by the states; ${ }^{22}$ and (3) federal securities law should limit itself to disclosure at most and not attempt substantive regulation of corporate governance. ${ }^{23}$ Their underlying theory comes very close to asserting that democracy is bad for corporate efficiency, and thus legislative inertia should be encouraged.

This Article is not a response to Professor Romano's sunset proposal. That idea is unlikely to gain any serious traction outside the small community of free market and libertarian theorists who believe financial markets are naturally self-regulating. This Article is, however, a response to the worldview these scholars favor and an attempt to focus attention on the critical implementation stage at which reform legislation is regularly frustrated. Here, one must acknowledge that the Tea Party Caucus is having an impact, particularly as they shift their focus from SOX to the Dodd-Frank Act where the stakes are higher. With the same fervor they once used to attack SOX, the Tea Party Caucus now seeks to dismantle the Dodd-Frank Act, which they also view as imposing "quack corporate governance" on the financial markets. ${ }^{24}$

rate law. See Stephen M. Bainbridge, Dodd-Frank: Quack Federal Comporate Governance Round II, 95 MinN. L. Rev. 1779, 1786-88 (2011); Ribstein, Bubble Laws, supra note 19, at 97.

22 See Ribsein, Market vs. Regulatory, supra note 19, at 57-61.

23 Professor Romano argued that the federal securities laws historically avoided substantive regulation of corporate behavior, staying safely "within a disclosure regime." See Roberta Romano, Does the Sarbanes-Oxley Act Have a Future?, 26 YALE J. on Reg. 229, 231 (2009). The distinctive failure of SOX in her view "is its break with the historic federal regulatory approach of requiring disclosure and leaving substantive governance rules to the states' corporation codes." Id. at 232; see also Ribstein, International Implications, supra note 19, at 300-05 (discussing the "potential shift in the philosophy underlying the U.S. securities laws from disclosure to substantive regulation of corporate governance"). This is a dubious historical generalization. Although the Securities Act of 1933 and the Securities Exchange Act of 1934 do utilize disclosure as their preferred tool, the federal securities laws have frequently regulated substantive corporate conduct and governance. The most controversial federal securities statute of the 1930s was the Public Utility Holding Company Act of 1935, which imposed a "death sentence" on public utility pyramids and holdingcompany structures-a clear example of aggressive substantive regulation. See Seligman, supra note 2, at 122-23 (describing the Public Utility Holding Company Act as "the most radical reform measure of the Roosevelt administration"). Similarly, the Investment Company Act of 1940 (ICA), which initially required that disinterested directors compose a minimum $40 \%$ of each investment company's board, regulates the board structure of investment companies. See id. at 228. The ICA also compels investment companies to hold a diversified portfolio and not short sell securities-again substantive regulation. See id. at 228-29. More recently, as Professor Romano acknowledges, the Foreign Corrupt Practices Act required stronger internal controls over financial reporting and prohibits certain questionable payments to political officials and candidates. See Romano, supra, at 231. Thus, SOX was only a break with an imagined past in which the federal securities laws exclusively required disclosure.

24 See Bainbridge, supra note 21, at 1796-1819. Like Professor Romano, Professor Bainbridge is also wary of "suspect policy entrepreneurs" who were in his view seeking "to advance a long-standing political agenda." See id. at 1815-16. For Professor Bainbridge, the "suspect policy entrepreneurs" are activists within the "institutional investor commu- 
In response, this Article argues that the Tea Party Caucus' shared thesis is unsound for at least three reasons: (1) unhappy as they may be with democratic majorities, they have no coherent theory that explains why democratic majorities should be constrained in their ability to act after a crisis; ${ }^{25}$ (2) they fail to understand the ease with which legislative mistakes or misjudgments can be corrected in the process of administrative implementation; ${ }^{26}$ and (3) even if one concedes that legislative misjudgments are often made, their proposed reforms, most notably the mandatory sunset provision, are an unnecessary fifth wheel, given the ease with which business interest groups can push back, repealing or downsizing legislation whenever they can make a colorable case that the legislation's costs exceed its benefits. Although Professor Romano argues that it would "take a Herculean effort to repeal [SOX's reforms] given the organization of government," 27 one has to wear blinders to reach this assessment. The downsizing of SOX, as later detailed, began quickly after its passage in 2002 and continues to date. Legislative efforts to repeal or downsize much of the Dodd-Frank Act are already well advanced. ${ }^{28}$ Professor Romano and her allies miss exactly what Mancur Olson would likely predict: once a crisis subsides, more organized interests groups regain the upper hand and begin to extract concessions, exemptions, or outright repeal.

nity, especially union and state and local pension funds." See id. Citing Professor Romano, he speculates that these activists are seeking to "reap private benefits not shared with other investors." See id. at 1816. Although this could conceivably be true in some instances, Professor Bainbridge provides little, if any, evidence and wholly ignores the even greater possibility that the business interests resisting "reform" are also seeking to gain or protect private benefits of their own. For example, corporate executives opposed to "say on pay" or other compensation reforms have a clearer self-interest and more evident desire for private benefits than do the public pension funds that favor "say on pay."

Professor Romano has also made clear that she views the Dodd-Frank Act as defective as SOX. See Romano, supra note 18, at 9-11.

25 Of course, reasonable people can disagree about the costs and benefits of most statutes. But the claim Professor Romano and her allies make is that post-crash legislation almost invariably fails. This is a heroic claim that must also consider the costs of crashes in underregulated markets in its cost/benefit calculus. Professor Romano's distinctive claim is that policy entrepreneurs incorporate their preconceived policy agendas into hasty legislation. See Romano, supra note 13, at 1568-69. Ultimately, everyone has preconceived ideas to which they turn in a crisis, and, as later discussed, the core ideas underlying SOX came from the SEC, the administrative agency with the most information and experience in the field, not from some idiosyncratic lone Congressman.

26 See infra notes 61-62 and accompanying text (discussing the Securities and Exchange Commision's exemptive authority under the federal securities laws). Professor Romano at no point discusses this exemptive authority, which permits the SEC to escape overly burdensome regulation without the need for legislative action. Perhaps, she believes liberal policy entrepreneurs have captured the SEC, but her silence on this point is revealing.

27 See Romano, supra note 18, at 6-7.

28 See infra notes $240-48$ and accompanying text. 
Interestingly, the erosion of SOX has had almost nothing to do with the weaknesses diagnosed by Professor Romano-for example, the haste surrounding its passage or the asserted lack of empirical evidence supporting its reforms. ${ }^{29}$ Rather, what most motivated the opposition to SOX were the high costs of the SOX Section 404 requirement for tighter internal controls on financial reporting. ${ }^{30}$ Yet, these costs resulted not from the legislation itself, but from unanticipated, postenactment administrative action. ${ }^{31}$ Administrative and legislative actions have already reduced those costs, but the business community remains unsatisfied and senses that complete victory is obtainable. ${ }^{32}$ Given their relative success, this episode hardly evidences the need for sunset provisions, as the business community seems more than capable of protecting its own interests.

Similarly, as the opposition to the Dodd-Frank Act mounts, this counterreaction is driven by attempts to protect executive compensation, high leverage, bank profitability, and managerial discretioneach of which has powerful champions. In contrast, the goal of curbing systemic risk has no obvious political champion among the usual participants in the political process surrounding financial regulation. ${ }^{33}$ Given the resulting imbalance, Mancur Olson's model predicts the likely outcome: interest-group politics will produce a major downsizing in the Dodd-Frank Act, both by way of administrative implementation and legislative revision.

Although SOX and the Dodd-Frank Act share many similarities, two major differences stand out and suggest that the Dodd-Frank Act is particularly vulnerable. First, the Dodd-Frank Act has a narrower focus than SOX and intends reforms that could prove more costly to financial institutions than any SOX provision. Although the DoddFrank Act also makes some attempts to regulate corporate governance at public corporations, it concentrates to a greater extent on the prob-

29 See Romano, supra note 18, at 6-7.

30 See 15 U.S.C. $\$ 7262$ (2006). For a more detailed discussion of this provision, see infra notes $73-87$ and accompanying text.

31 As later discussed, the high costs of Section 404 came not from any provision of the statute, but from action taken by the self-regulatory Public Company Accounting Oversight Board (PCAOB), which required that the auditors conduct a full-scale audit before attesting under Section 404(b) to management's evaluation of its internal controls. See infra notes 73-86 and accompanying text. Section 404 of SOX imposed only the requirement that the auditor "attest to . . . the assessment made by the management." Sarbanes-Oxley Act of 2002, Pub. L. No. 107-204, §404, 116 Stat. 789 (codified at 15 U.S.C. $\$ 7262$ (2006)). Section 404 is hardly evidence of legislative haste or of a populist eruption. A cynic might attribute the high costs of a Section 404 audit to either a desire on the part of the accountants' self-regulator to benefit accountants with high fees or to the limited competition within the highly concentrated accounting industry.

32 See infra notes 89-92, 240-48 and accompanying text.

33 See infra notes 48-52 and accompanying text. 
lem of systemic risk at large, "too big to fail" financial institutions. ${ }^{34}$ Unfortunately, systemic risk is a complex and relatively opaque concept with which the average citizen does not easily identify. ${ }^{35}$ Second, the Dodd-Frank Act depends upon administrative implementation to a far greater degree than did SOX because Congress simply could not specify in detail the proper implementation with respect to capital adequacy, liquidity ratios, over-the-counter (OTC) derivatives, and similar complex financial issues applicable mainly to large financial institutions. For both reasons, the Dodd-Frank Act is particularly exposed to downsizing in the posteuphoric period after legislation passes when the public's attention turns elsewhere and business interest groups reestablish their usual dominance over the technical policy implementation process.

If one believes that systemic risk is a serious problem requiring rigorous attention, this vulnerability is disquieting because subsequent legislation, equivocal agency rule-making, judicial hostility, and timid underenforcement by regulators effectively pared back SOX in the period after its passage. ${ }^{36}$ That pattern may well repeat-with the result that adequate protections against systemic risk will not be implemented. This claim does not rest on the premise that the financial industry simply "captures" regulatory agencies, ${ }^{37}$ but that the industry tends to gain influence at the administrative implementation stage, forcing regulators to trim their sails. Not only does the administrative stage have inherently lower visibility and is at least as susceptible to lobbying pressure (because of the influence of the "revolving door" on bureaucratic staffers who expect to eventually return to the financial industry ${ }^{38}$ ), but industry efforts at this later, more pedestrian stage are less likely to attract challenges from political entrepreneurs who appear in crises to champion the cause of investors.

A roadmap of this Article is now in order. Part I of this Article presents a model of how financial reform legislation is frustrated and downsized. This model does not depend on "capture" by the industry ${ }^{39}$ but rather applies the insights of Mancur Olson, among others,

34 See infra Part III.B.

35 See infra note 163 and accompanying text.

36 See infra notes 80-89 and accompanying text.

37 The term "capture" is inherently elusive and suggests that a permanent victory is won by the industry. In contrast, this Article suggests that the opposing sides can each dominate at various points, but the forces championing public-regarding legislation are only advantaged after a major crisis.

38 The press increasingly debates this topic. See Andrew Ross Sorkin, The S.E.C.'s Revolving Door, N.Y. TIMES, Aug. 2, 2011, at B1.

39 Professor Romano asserts that this author assumes that the financial industry captured administrative agencies. See Romano, supra note 18, at 18-19. No such assumption is made, but a hostile Congress, with control over agencies' budgets, may intimidate some resource-constrained agencies. 
to the real world of lobbying and administrative implementation. Part I contrasts this model with that offered by Professor Romano and her allies. Next, on the premise that what is past is prologue, Part II of this Article examines how SOX's provisions were weakened, abandoned, or downsized at the implementation stage. Such administrative softening, or even abandonment, of legislative enactments may be even more likely in the case of the Dodd-Frank Act because (1) the prospective costs to the financial industry are higher, (2) the DoddFrank Act has no natural allies among the major political players who usually support reform legislation applicable to the financial markets, ${ }^{40}$ and (3) the Act is even more dependent on administrative implementation and rule-making. Part III examines the policy premises underlying the Dodd-Frank Act. Rather than idealize this legislation, Part III acknowledges that some of the Act's reforms were flawed or even inconsistent. But legislation in the real world is always imperfect-this is the consequence of the logrolling and compromise needed to assemble a majority in a divided political environment. Part IV then turns to the implementation of the Dodd-Frank Act and the associated legislative and judicial attempts to downsize it. To date, the evidence suggests that a crisis is being wasted, and thus the danger of future systemic-risk catastrophes remain clear and present. All this will set the stage for a concluding section that will ask and only partially answer the ultimate question: what reforms could work?

I

The Regulatory Sine Curve and Statutory Correction

This Article's fundamental premise is that a "Regulatory Sine Curve" governs the intensity of the oversight exercised by financial regulators. By this phrase, it is meant both that (1) regulatory oversight is never constant but rather increases after a market crash and then wanes as, and to the extent that, society and the market return to normalcy, and (2) the public's passion for reform is short-lived and the support it gives to political entrepreneurs who oppose powerful interest groups on behalf of the public also quickly wanes. This same pattern may characterize other forms of regulation-for example, environmental regulation may wax and wane with highly publicized, vivid environmental disasters-but important differences exist. Financial regulation is inherently opaque, and the public lacks the same visceral identification with the key values in play-few care as passionately about systemic risk as they care about the environment or civil rights. Thus, the public's attention span is shorter, and the window of opportunity briefer within which Congress can pass reform legislation.

40 See infra notes 47-52 and accompanying text. 
The key implication of the Regulatory Sine Curve is not that legislation is futile, but that erosion of the statute's commands will predictably begin shortly after its passage. Core provisions of the legislation will likely remain (just as the core provisions of the federal securities laws, including those of SOX, remain in place), and sometimes courts may expansively fill in the legislation's gaps. ${ }^{41}$ Nonetheless, the greater the legislation's reliance on administrative implementation, the greater the erosion that becomes likely-at least if the legislation conflicts with the industry's preferences. This perspective posits both that downsizing and correction is inevitable and that to a degree correction may often be desirable. But the likelihood of such erosion also justifies strong legislative action in the first instance and the framing of some key policies in prophylactic terms that prevent or retard their erosion. This perspective fundamentally conflicts with Professor Romano and the Tea Party Caucus, who believe that reform legislation passed after a crash will always enact foolish "quack cures" and should be discouraged.42 For both sides, a common starting point is the recognition that (1) legislation is often flawed, and (2) SOX and the Dodd-Frank Act have their own curious, overbroad, and inconsistent elements. But this Article responds that the likelihood of legislative errors and misjudgments hardly merits Draconian measures, such as a sunset provision, because "correction" is possible through a variety of less drastic and more feasible means and is probably inevitable in light of the Regulatory Sine Curve.

The standard cyclical progression along the Regulatory Sine Curve from intense to lax enforcement is driven by a basic asymmetry between the power, resources, and organization of the latent group (i.e., investors) and the interest groups affected by the specific legislation. Cohesion among investors begins to break down once "normalcy" returns. Professor Romano disputes this view of investors as a dispersed latent group, ${ }^{43}$ arguing: (1) that "well-funded and politically influential labor unions, public pension funds, and the plaintiff's bar" effectively represent investors in the typical legislative battles over financial regulation, ${ }^{44}$ and (2) that business is not "monolithic" but has often conflicting interests. ${ }^{45}$

41 Certainly, the federal courts aggressively filled in the gaps in the federal securities laws in the 1960s by, among other things, implying private causes of action. See J. I. Case Co. v. Borak, 377 U.S. 426, 430-31 (1964) (implying a private cause of action to enforce federal securities laws). That period of liberal construction of the federal securities laws since ended, but courts may uphold or invalidate administrative rules implementing the Dodd-Frank Act to the extent they understand and accept the purpose of the legislation.

42 See, e.g., Romano, supra note 13, at 1526-27.

43 She acknowledges that her work never discusses Mancur Olson or related theorists and asserts that "it would be a mistake to do so." See Romano, supra note 18, at 20 n.11.

44 See id. at 21.

45 See id. 
Both claims are easily refuted. The claim that investors have powerful champions with equal political influence fails for at least three independent reasons. First, the contest for political influence pits the financial services industry (and those corporate insiders who do not want executive compensation limited or shareholder power strengthened) against investors. This is an inherently one-sided battle, as most recent studies find that business groups dominate the lobbying process. ${ }^{46}$ To consider public pension funds a counterweight to major financial institutions is to mistake an ox for a bull. Pension funds, as fiduciaries for their beneficiaries, do not make political contributions and are thus relatively impotent as political actors. Labor unions can lobby and make political contributions, but their political power has steadily subsided for decades as the percentage of the unionized U.S. work force has declined. ${ }^{47}$ The plaintiff's bar may be active in politics, but major financial institutions dwarf its financial resources. As a practical matter, both unions and the plaintiff's bar largely limit their efforts to the Democratic side of the political aisle, while business groups contribute heavily to both sides and thus have broader political access. ${ }^{48}$

Second, even if institutional investors make some effort to lobby for protection against systemic risk, they logically will spend less than

46 Political scientists have assembled a great deal of evidence on this score. As one survey by them summarizes: "Whether we measure it by organizations represented, by money spent, by issues acted on, or participation in rule-making, we see that businesses and trade associations consistently mobilize at roughly ten times the rate that those forces that might countervail them do." Dorie Apollonio, Bruce E. Cain \& Lee Drutman, Access and Lobbying: Looking Beyond the Corruption Paradigm, 36 HASTINGs ConsT. L.Q. 13, 47 (2008) [hereinafter Apollonio]. This study reports data on lobbying expenditures and finds that business constitutes $71.7 \%$ of such expenditures while labor constitutes only $4.2 \%$. See id. at 50 tbl.2. Examining spending on federal lobbying, the report finds that the combined finance, insurance, and real estate sector is the single largest spender, while labor ranks only eighth. See $i d$. at tbl.3. Finally, focusing on past disparities in political and lobbying expenditures may result in overlooking the growing prospective disparity, given the significance of the Supreme Court's decision in Citizens United v. FEC, $130 \mathrm{~S}$. Ct. 876, 886 (2010), which holds that the First Amendment protects a corporation's right to make certain political contributions. New evidence shows that corporate political and lobbying expenditures significantly increased in the wake of the Citizens United decision. See John C. Coates, IV, Corporate Politics, Governance and Value Before and After Gitizens United 23 (Jan. 25, 2012) (unpublished manuscript), available at http://papers.ssrn.com/sol3/ papers.cfm?abstract_id=1975421.

47 Apollonio, Cain, and Drutman report that in 2006 the combined finance, insurance, and real estate lobby expended $\$ 258.9$ million, while the labor lobby expended $\$ 66.6$ million-a roughly four-to-one ratio. See Apollonio, supra note 46 , at 50 tbl.3. Of course, these amounts understate the real disparity because political contributions and lobbying by labor almost certainly concentrates not on financial sector issues, but on traditional labor issues.

48 Apollonio, Cain, and Drutman report data showing that the combined finance, insurance, and real estate lobby allocates its expenditures $54 \%$ to Republicans and $44 \%$ to Democrats, while the labor lobby allocates $12 \%$ to Republicans and $87 \%$ to Democrats. See id. 
the entire class of investors would rationally spend. Institutional investors represent just over half of all investors ${ }^{49}$ and because they will receive only roughly half of the benefits from increased protection, they can be expected to spend only half of what all investors might pay. ${ }^{50}$ But collective-action problems impede any attempt to tax other investors, and thus a shortfall results. On the other side of the equation, corporate insiders may use corporate funds to lobby, thereby expending investors' money to reduce investor welfare. Simply put, this is a mismatch.

Third, the interest groups pointed to by Professor Romano-unions, public pension funds, and the plaintiff's bar-have interests that conflict with other public investors' interests and that compromise their asserted role as champions for investors generally. To the extent that closer regulation of banks and financial institutions would restrict their ability to increase lending or to underwrite subprime mortgages, such a policy is contrary to the natural interests of unions, which tend to favor easy credit and increased lending. After all, increased lending creates jobs and job creation is a principal goal of both labor and some civil-rights groups. In short, those seeking to reduce systemic risk have few natural political allies; it is a cause that unites largely the technocrats.

Professor Romano's other claim that business is not "monolithic" is, of course, correct to a degree. ${ }^{51}$ Often, business interest groups do battle each other. But the interests of the financial services industry are remarkably well aligned in opposing increased regulation of their capital structure, leverage, executive compensation, and risk management policies, and they have been both vocal and united in claiming that the Dodd-Frank Act places them at a competitive disadvantage in an increasingly global marketplace. ${ }^{52}$ At a minimum, the business community shares a common desire to resist the encroachment of regulatory power over their capital, leverage, and compensation decisionmaking. Understandable as it is that they resist, regulatory oversight

49 Institutional investors hold slightly over $50 \%$ of the equity in U.S. public corporations. See Matteo Tonello \& Stephan Rabimov, The 2010 Institutional Investment Report: Trends in Asset Allocation and Pontfolio Composition, 2010 The Conference Board Research REPORT R-1468-10-RR, at 22 tbl.10.

50 This point is well made in Lucian A. Bebchuk \& Zvika Neeman, Investor Protection and Interest Group Politics, 23 Rev. Fin. STUD. 1089, 1090-91 (2010).

51 See Romano, supra note 18, at 21.

52 Indeed, Professor Romano argues that much of the business community is united in opposition to the Dodd-Frank Act, believing it has "exacerbated the severe economic downturn that has followed the global financial crisis." See id. at 9. For a representative and revealing statement by the financial services industry that it considers both the DoddFrank Act and Basel III a threat to the U.S. economy and international competitiveness, see Press Release, Fin. Servs. Roundtable, Rules Present a Grave Threat to the Economy (Oct. 3, 2011). 
of these areas is exactly what the goal of limiting systemic risk requires.

Professor Romano proceeds directly from her premise that reform legislation is always flawed to her conclusion that mandatory sunset legislation is necessary. Others point out that the mandatory sunset remedy lacks any serious empirical support. ${ }^{53}$ This seems a curious omission for someone whose primary objection to reform legislation is that Congress did not wait for empirical research to discover the optimal remedy. ${ }^{54}$ Still, in the absence of empirical research, it is useful to ask two questions: (1) What are the likely consequences of a sunset requirement? and (2) What are the less drastic alternatives to Professor Romano's proposed sunset rule?

With regard to the first question, any mandatory sunset remedy would greatly compound the existing imbalance between the resources of the contending sides in legislative battles over financial regulation. The "reform" side would have to win twice, with the latter battle coming after the crisis subsides. Also, the side seeking to "sunset" the legislation might be able to win by virtue of a minority vetofor example, because of a blocking position on a key committee or a filibuster. It was for this reason that Justice (then Professor) Breyer in a well-known book on reforming the administrative process decided that a mandatory sunset law was too Draconian a remedy. ${ }^{55}$ Further, to the extent that the recurring battle over financial regulation is between those who want more regulation and those who want less, a sunset remedy is inherently one-sided because it applies only to legislation that imposes new regulation and not to legislation that repeals existing regulation. In truth, deregulation can equally be achieved in haste, with the consequence being ill-considered "reforms" that expose financial markets to catastrophe. ${ }^{56}$ If Professor Romano's rem-

53 See Prentice \& Spence, supra note 8, at 1855-56 (noting that Professor Romano "offers no evidence that laws enacted in a short time frame tend to have more problems than laws enacted over a longer period" and "no empirical evidence that sunshine provisions provide any benefits on balance"). It seems ironically inconsistent for Professor Romano to criticize Congress for enacting many of SOX's provisions without (in her view) adequate empirical support and then in turn propose a legislative remedy of her own (a mandatory sunset rule) that also has no empirical support.

54 Although Professor Romano believes there is "long and well-established U.S. experience with sunset legislation," she concedes that " $[\mathrm{t}]$ here is . . a dearth of research empirically analyzing sunset reviews," and the research that does exist is "mostly qualitative." Romano, supra note 18 , at 17 n.9. In short, her own proposal does not have the empirical foundation that she insisted SOX and the Dodd-Frank Act needed.

55 See Stephen Breyer, Regulation and Its Reform 366-67 (1982).

56 A good example of hasty deregulatory legislation is the Commodity Futures Modernization Act of 2000 (CFMA), Pub. L. No. 106-554, 114 Stat. 2763, 2763A-365 (codified in scattered sections of $7,11,12$, and 15 U.S.C. (2006)), which exempted over-the-counter derivatives, including swaps, from the jurisdiction of both the Commodities Future Trading Commission and the Securities and Exchange Commission. The CFMA's wholesale deregulation of swaps in 2000 set the stage for AIG's collapse in 2008 when AIG could no 
edy were truly evenhanded, it would apply to deregulatory provisions as well. Either way, the cost of such a remedy is continuing uncertainty and potential paralysis, as nothing could be assumed as permanent. ${ }^{57}$

To disagree with Professor Romano's reforms, it is not necessary to take the opposite position to her on all issues. One need not claim that reform legislation is typically carefully written or well planned. Rather, this Article starts from the view stated by Otto von Bismarck over a century ago when he compared the framing of legislation to the making of sausage. ${ }^{58}$ Political compromises are often unprincipled, odd, and place together strange bedfellows. Haste contributes to this state of affairs, ${ }^{59}$ but it is only one of many factors. Indeed, it is not clear that slow and piecemeal legislative reform is any less flawed. ${ }^{60}$

Even if haste does produce error, as seems logical, this risk does not imply that reformers should remain passive after a financial crisis.

longer honor the enormous commitments that it made by means of unregulated credit default swaps. See infra notes $126-27$ and accompanying text.

57 For example, if pursuant to such an evenhanded sunset, Congress subjected the CFMA to an automatic termination if not reaffirmed within five years, the institutions writing credit default swaps over this interim might have faced considerable uncertainty that could have chilled their willingness to enter this field. Even more frightening is the idea that the Federal Reserve Board could similarly vanish if a polarized Congress could not act within Professor Romano's proposed deadline.

58 Otto von Bismark (1815-1898), the Chancellor of Imperial Germany, reputedly said: "Laws are like sausages, it is better not to see them being made." See BrainY Quote, http://www.brainyquote.com/quotes/authors/o/otto_von_bismarck.html (last visited Mar. 2, 2012).

59 In fact, courts have noted that SOX was "hastily passed and poorly drafted." Newby v. Enron Corp., 2004 U.S. Dist. LEXIS 8158, at *46 (S.D. Tex. Feb. 25, 2004) (internal quotation marks omitted); see In re Adelphia Commc'ns. Corp. Sec. and Derivative Litig., 2005 U.S. Dist. LEXIS 10349 , at $* 20$ n.8 (S.D.N.Y. May 27, 2005). On the other hand, other commentators observe that drafting ambiguities that are eventually corrected or clarified arise in all major legislation. WorldCom corporate monitor and former SEC Chairman Richard C. Breeden wrote:

While Sarbanes-Oxley has been criticized in some quarters, there can be no doubt that it addresses some of the very problems presented by this Company's history. . . As with other major legislation covering significant new territory, there are provisions of Sarbanes-Oxley that will benefit from either clarifying regulations or from exemptive actions.

Richard C. Breeden, Restoring Trust: Report to the Hon. Jed S. Rakoff the United States District Court for the Southern District of New York on Corporate GovernANCE FOR THE FUtUre OF MCI, INC. 38 \& n.43 (2003), available at http://www.sec.gov/ spotlight/worldcom/wcomreport0803.pdf. This Article agrees with Chairman Breeden: whether Congress adopts comprehensive legislation deliberately or in haste, a corrective process naturally follows.

60 Congress passed the Banking Act of 1933 (Glass-Steagall Act), ch. 89, 48 Stat. 162 (codified as amended in scattered sections of 12 U.S.C.), separating investment banking from commercial banking in haste in 1932, then repealed it slowly over several decades, culminating with the Gramm-Leach-Bliley Act, Pub. L. No. 106-102, 113 Stat. 1338 (1999) (codified as amended in scattered sections of 12 and 15 U.S.C. (2006)). Reasonable persons can disagree over which statute was more flawed. 
At worst, they will face an imperfect choice: act quickly and imperfectly within a brief window of opportunity or face the likelihood that the forces of legislative inertia will regain the upper hand and prevent any reform. In fact, however, the choice is usually less stark. The key lesson from reviewing the response to SOX is that the "correction" of reform legislation is virtually inevitable. In turn, this undercuts the case for legislative passivity or mandatory sunsets. Those whose oxen are gored will predictably organize to secure relief. As later described, SOX exemplifies this pattern.

Accordingly, what is the best, most feasible remedy for legislative error and misjudgment? In this Article's view, it is the remedy that already exists under the federal securities laws and that Professor Romano never discusses. Under Section 36 of the Securities Exchange Act of 1934, the SEC possesses "[g]eneral exemptive authority" and can:

[C]onditionally or unconditionally exempt any person, security, or transaction, or any class or classes of persons, securities or transactions, from any provision or provisions of this chapter or of any rule or regulation thereunder, to the extent that such exemption is necessary or appropriate in the public interest, and is consistent with the protection of investors. ${ }^{61}$

This fairly sweeping language gives broad authority to the administrative agency, which has the benefit of greater information and postenactment experience to override Congress.

The advantages of such an administrative exemptive approach are that, under it, delay, stalling tactics, or a minority veto could not overturn a prior congressional enactment. Uncertainty is also reduced, as an administrative agency, with greater experience and objectivity, must be persuaded to act. The agency's actions are likely to be more predictable and more incremental, thus avoiding the uncertain all-or-nothing choice inherent in sunset provisions. Only if one believes that the SEC has been "captured" by an interest group does this more tailored and precise remedy seem inferior to a gamble on a sunset provision. ${ }^{62}$

In sum, the contrast between the Tea Party Caucus's perspective and that taken here is basic, but both share some common elements. In Profesşor Romano and her allies' worldview, reform legislation follows "a media clamor for action," 63 and this "'media frenzy' . . com-

61 See 15 U.S.C. $\$ 78 \mathrm{~mm}$ (a) (1). Similar exemptive provisions are set forth in Section 28 ("General Exemptive Authority") of the Securities Act of 1933, 15 U.S.C. $\$ 77 z-3$, and Section 206A ("Exemptions") of the Investment Advisers Act of 1940, 15 U.S.C. \$ 80b-6a.

62 Because Professor Romano never discusses the option of agency exemptive authority, one cannot know her criticisms of it, if she was aware of these provisions.

63 See Romano, supra note 18 , at 4. 
pels legislators not only to respond, but to respond quickly, even though they . . . cannot possibly determine what would be the best policy to adopt in the circumstances." 64 Typically, she argues, they adopt "recycled proposals fashioned to resolve quite unrelated problems, imagined or real, which policy entrepreneurs advance as ready-made solutions to immediate concerns, to a Congress in need of off-the-shelf proposals that can be enacted quickly." 65 Further, Congress, because it is risk averse and self-interested, delegates great discretion to administrative agencies as "a means by which legislators can avoid responsibility for adverse policy consequences." 66

The alternative view, here presented, agrees that crisis is a precipitant, allowing legislative inertia to be overcome. After a crisis, Congress tends to adopt proposals long-favored by the relevant administrative agency but frustrated by powerful lobbies. Only with a crisis can reformers-or "political entrepreneurs" in the political science vernacular-aggregate sufficient support to pass reform legislation. For example, in the years prior to the Enron and WorldCom crisis in 2001 and 2002, SEC Chairman Arthur Levitt sought to respond to a soaring number of financial statement restatements and campaigned to restrict auditor conflicts of interest. ${ }^{67}$ Levitt was rebuffed, however, by the industry. ${ }^{68}$ With the Enron and WorldCom insolvencies and the evidence of financial impropriety manifest to all, Levitt and others-most notably, Senator Paul Sarbanes-convinced Congress to replace auditor self-regulation with a new body: the Public Company Accounting Oversight Board (PCAOB). ${ }^{69}$ The PCAOB

64 See id. at 5-6.

65 See id. at 6 .

66 See id. at 8.

67 See Prentice \& Spence, supra note 8, at 1852 (reporting that Levitt "had been warning of conflicts of interest and other structural problems in the accounting industry"). Publicly traded companies financial statement restatements rose from 49 in 1996 to an estimated 250 in 2002, or an increase of approximately $270 \%$ over this five-year period ending in 2002. See Coffee, supra note 3, at 283.

68 Even Professor Romano recognizes that "the provision of nonaudit services by auditors had been subject to persistent efforts at elimination by the SEC prior to SOX's prohibition." See Romano, supra note 13, at 1534. Thus, the SOX provisions that Romano most objects to did not come from the liberal constituencies of which she is suspicious (i.e., unions, public pension funds, and the plaintiff's bar), but from the administrative agency with the most experience in the field. This does not fit her diagnosis that, in a crisis, Congress turns to the pet ideas of special-interest groups or individual Congressmen and adopts them without careful evaluation. Similarly, Professor Bainbridge claims that "suspect policy entrepreneurs" conspire to "hijack the legislative process to advance a longstanding political agenda." Bainbridge, supra note 21, at 1815-16. Because the principal administrative agency in the field detected a clear decline in the performance of a critical gatekeeper, this simply did not happen in the case of SOX. See supra note 67 and accompanying text.

69 Title I of SOX establishes the PCAOB and specifies the Board's powers. See Sarbanes-Oxley Act of 2002, Pub. L. No. 107-204, $\$ \S 101-110,116$. Stat. 745, 750-71 (codified at 15 U.S.C. $\$ \S 7211-20(2006)$ ). 
was the centerpiece of SOX, but it was hardly an "off-the-shelf" proposal. But for the crisis, auditor self-regulation would have persisted. Depending on one's preferred perspective, Levitt and Sarbanes are either the heroes or villains of this story. ${ }^{70}$

But the story does not end there. "Correction" does follow, both in the form of administrative rules that soften legislative commands and in the form of legislation curbing the prior statute. The next Part of this Article describes this process in greater detail and as it applied to SOX. A later section will turn to the Dodd-Frank Act. Reasonable persons can disagree about whether this corrective process went too far, as this author believes, or not far enough. Still, correction is an inevitable part of the Regulatory Sine Curve, which is examined next in operation.

\section{II}

\section{SOX REvisited: The DOWNSIZING OF REFORM}

Professor Romano's article on "Quack Corporate Governance" focused on four areas where, in her view, empirical academic literature did not support SOX's reforms: (1) independent audit committees, (2) the restrictions on auditors providing nonaudit services to audit clients, (3) executive certification of financial statements, and (4) executive loans. ${ }^{71}$ The efforts to revise or downsize SOX largely ignored the first three of these areas. In contrast, the private bar organized a quiet campaign, acquiesced in by the SEC, to effectively curtail the prohibition on executive loans. ${ }^{72}$ Neither SOX's proponents nor its critics appear to have been influenced by the weight of academic empirical research. Instead, the business community focused primarily on softening the SOX Section 404 requirements, which required an annual independent review of a public company's internal controls that proved more costly than anticipated.

This Part will focus on those areas where SOX encountered the greatest resistance or has been the most abandoned: (1) Section 404, (2) executive loans, and (3) Section 307, which required lawyers representing the corporation to report securities and similar violations up the corporate ladder.

\section{A. Section 404 and Internal Control Reports}

Although SOX Section 404 became highly controversial in time, it was initially a sleeper provision that attracted comparatively little

\footnotetext{
70 Professor Romano has made it very clear that she considers both to have been policy entrepreneurs who foisted flawed legislation on the country. See Romano, supra note 13 , at $1549-51,1584$.

71 See id. at 1529-43.

72 See infra notes 94-106 and accompanying text.
} 
attention. As passed, it mandated only that the SEC adopt a new "internal control report" to be included in the issuers' annual report on Form $10-\mathrm{K}^{73}$ In this report, management was to assess the effectiveness of management's internal controls over financial reporting. ${ }^{74}$ Section 404(b) then required the company's outside auditor to "attest to, and report on" management's assessment..$^{75}$ Such an attestation requirement was not inherently costly. What in fact made this provision costly and controversial was the PCAOB's decision, two years after SOX's passage, to require a full-scale audit of the issuer's internal controls before the auditor might so attest. Under its Auditing Standard No. 2, adopted in 2004, the PCAOB required an auditor to test and evaluate both the design and operating effectiveness of the issuer's internal controls before it could deem itself satisfied with management's own assessment requirement. ${ }^{76}$ This effectively implied that the auditor must conduct two full audits: first, a traditional audit of the issuer's financial statements and, second, an audit of the issuer's internal controls.

This requirement proved expensive to issuers (and profitable to auditors) and provoked a predictable political reaction. ${ }^{77}$ Büt the decision to require a full audit was not the product of SOX, itself. The accounting profession largely welcomed this dual audit requirement, which proved very lucrative for them. ${ }^{78}$ Nonetheless, even if auditors were happy with this rule, issuers were not. Almost immediately following the 2004 adoption of Auditing Standard No. 2, issuers and

73 Section 404(a) of Sarbanes-Oxley Act ("Management assessment of internal controls") requires an annual "internal control report" that contains "an assessment, as of the end of the most recent fiscal year of the issuer, of the effectiveness of the internal control structure and procedures of the issuer for financial reporting." See 15 U.S.C. $\$ 7262$. Section 404(b) provides that the issuer's management should prepare this report. See id.

74 See id.

75 See id. Section 404(b) then added that this attestation "shall be made in accordance with standards for attestation engagements issued or adopted by the [Public Company Accounting Oversight] Board." See id.

$76 \quad$ See Order Approving Proposed Auditing Standard No. 2, Exchange Act Release No. $49,884,69$ Fed. Reg. 35,083, 35,083-84 (June 23, 2004). The PCAOB's authority to adopt this rule came from Section 404(b). See 15 U.S.C. $\$ 7262(\mathrm{~b})$.

77 See generally Transcript, Roundtable Discussion on Second-Year Experiences with Internal Control Reporting and Auditing Provisions, SEC (May 10, 2006), available at http://www.sec.gov/spotlight/soxcomp/soxcomp-transcript.txt (discussing the concerns and reports of excessive expense of issuers attempting to apply Auditing Standard No. 2); Paul S. Atkins, Speech by SEC Commissioner: Remarks Before the International Corporate Governance Network 11th Annual Conference, U.S. SEC. AND Exchange Commission (Jul. 6, 2006), http://www.sec.gov/news/speech/2006/spch070606psa.htm (acknowledging the high cost of compliance with Section 404 "because of the excessive way in which accountants and management have implemented it").

78 See Sarbanes-Oxley Section 404: What is the Proper Balance Between Investor Protection and Capital Formation for Smaller Public Companies?: Hearing on H.R. 3763 Before the Comm. on Small Bus., 109th Cong. 9 (2006) (statement of Keith Crandell, Arch Venture Partners) (claiming that auditors had shifted their focus to "lucrative 404 practices"). 
others began to call for downsizing of the standard, particularly as applied to smaller public companies. ${ }^{79}$ In 2006, an SEC Advisory Committee recommended that this internal-controls audit be waived in the case of smaller companies, which it defined as those with a market capitalization under $\$ 125$ million. ${ }^{80}$ Foreign issuers began delisting from U.S. exchanges in significant numbers following 2000 and often pointed to Section 404 as a leading cause of their decision to flee the U.S. markets. ${ }^{81}$ Both actions successfully delayed the application of Section 404 to them. ${ }^{82}$

Finally, in 2007, the PCAOB replaced Auditing Standard No. 2 with Auditing Standard No. 5, which relaxed a number of Section 404's requirements. ${ }^{83}$ With the revision, the PCAOB intended to reduce audit costs, particularly for smaller companies. ${ }^{84}$ A follow-up SEC study of Section 404 found a significant decrease in audit costs as a result of the 2007 changes. ${ }^{85}$

Still, this marginal improvement did not satisfy Congress. The Dodd-Frank Act continued to downsize the internal controls audit by exempting from Section 404(b) issuers that were neither "accelerated filer[s]" nor "large accelerated filer[s]." ${ }^{86}$ Effectively, this meant that nonaccelerated filers (i.e., filers with a market capitalization of $\$ 75$ million or less) were still required to include management's evaluation of its internal controls in their annual report on Form 10-K, but no longer had to include their auditor's attestation to that report (which would have required an audit under the PCAOB's rules).$^{87}$

79 See, e.g., Exposure Draft of Final Report of Advisory Committee on Smaller Public Companies, Securities Act Release No. 8666, Exchange Act Release No. 53,385, 71 Fed. Reg. 11,090, 11,098 n.60 (Mar. 3, 2006) [hereinafter Release 8666].

$80 \quad$ See id. at 11,092-93.

81 See, e.g., Pernod Ricard SA, Annual Report (Form 20-F) at 15 (Dec. 20, 2006) (reporting the company's desire to terminate its 1934 Act registration and thus cease to be a "reporting company" was motivated in part by a desire to escape SOX); Photowatt Techs. Inc., Registration Statement (Form F-1) at 23 (Sept. 1, 2006) (complaining that Section 404 compliance is "expensive and time consuming" and carries serious risks of administration sanctions and related risks).

82 See Release 8666, supra note 79, at 11,103 .

83 See Order Approving Proposed Auditing Standard No. 5, Exchange Act Release No. 56,152, 72 Fed. Reg. 42,141, 42,141-42 (Aug. 1, 2007).

84 The SEC emphasized this likely cost reduction when it approved Auditing Standard No. 5. See id. at 42,145 (noting that those commenting on proposed Auditing Standard No. 5 believed it would reduce the costs of Section 404 compliance).

85 See U.S. Sec. \& Exch. Comm'n, Study and Recommendations on Section 404(в) of the Sarbanes-Oxley Act of 2002: For Issuers with Public Float Between $\$ 75$ and $\$ 250$ Million 49 n.86 (2011), available at http://www.sec.gov/news/studies/2011/ 404bfloat-study.pdf.

86 See Dodd-Frank Wall Street Reform and Consumer Protection Act (Dodd-Frank Act), Pub. L. No. 111-203, § 989G, 124 Stat. 1383, 1948 (2010) (codified at 15 U.S.C. $\S 7262$ (Supp. IV 2010)) (adding new Section 404(c) to the Sarbanes-Oxley Act of 2002).

87 See Internal Control Over Financial Reporting in Exchange Act Periodic Reports of Non-Accelerated Filers, Securities Act Release No. 9142, Exchange Act Release No. 62,914, 
The SEC further accommodated newer issuers by delaying Section 404's internal control attestations until a public company was required to file its second Form 10-K, effectively giving a company two years after its IPO before such a report was due. ${ }^{88}$

Even the Dodd-Frank Act's partial repeal of Section 404 did not end the push for still greater downsizing. In late 2011, the President's Council on Jobs and Competitiveness issued a report calling for the massive downsizing of SOX's requirements with respect to public companies with a market capitalization below $\$ 1$ billion. 89 Section 404 seems to be the primary target, but hardly the exclusive one. ${ }^{90}$ The proposed $\$ 1$ billion market capitalization cutoff would exempt roughly two-thirds of the approximately 5,700 public companies listed on major U.S. stock exchanges. ${ }^{91}$ This proposal elicited a sharp editorial rebuke from the New York Times, but has been incorporated in the recently enacted JOBS Act. ${ }^{92}$

Reasonable persons can debate the wisdom of the PCAOB's various actions both in requiring an audit of internal controls and then in sparing from that audit smaller issuers, which are actually more likely to experience internal control problems. ${ }^{93}$ But three conclusions seem justified: (1) administrative implementation by a politically neutral, self-regulatory organization caused the Section 404 crisis, not hasty congressional action; (2) a corrective process curbed much of the perceived problem within a few years of SOX's passage and may yet sweep away still more of SOX's provisions; and (3) Congress will not nullify Section 404, as the maximum proposed retrenchment would still leave the internal controls audit in place for larger companies with a market capitalization over $\$ 1$ billion. Again, critics may

75 Fed. Reg. 57,385, (Sept. 21, 2010) (adopting new rules in response to Section 989G of Dodd-Frank Act).

88 See 17 C.F.R. $\$ 229.308$ (2011). This provision permits new public companies to delay filing its management assessment of internal controls over financial reporting (and accompany auditor attestation) until the company's second annual report .

89 See President's Council on Jobs and Competitiveness, Taking Action, Building Confidence: Five Common-Sense Initiatives to Boost Jobs and Competitiveness 19 (2011), available at http://files.jobs-council.com/jobscouncil/files/2011/10/JobsCouncil_ InterimReport_Oct11.pdf.

90 See David Milstead, A Desperate Obama Kicks Investor Protection to the Curb, GLOBE AND MAIL, Oct. 18, 2011, at B19.

91 See id.

92 See Editorial, Not Their Job, N.Y. TIMEs, Oct. 20, 2011, at A24. The JOBS Act (an acronym for "Jumpstart Our Business Startups"), which has now passed both Houses of Congress, exempts "emerging growth companies," which are defined as companies with less than $\$ 1$ billion in gross revenues and $\$ 700$ million in public float, from Section 404(b) for a defined period, which is likely to be at least five years. See infra notes 240-48 and accompanying text.

93 For evidence in support of a strong internal controls audit requirement, see Robert Prentice, Sarbanes-Oxley: The Evidence Regarding the Impact of SOX 404, 29 CARDozo L. REv. 703, 711-25 (2007). This issue is not, however, the focus of this Article. 
debate whether this corrective process went too far or not far enough, but it exemplifies the Regulatory Sine Curve in operation. The DoddFrank Act is likely to receive similar treatment.

\section{B. Executive Loans and Section 402}

Section 402 of SOX is distinctive. Unlike other provisions of SOX or the Dodd-Frank Act that authorize agency rulemaking, Section 402 prophylactically prohibited public companies from arranging or extending credit to their executive officers or directors. ${ }^{94}$ Adopted with little discussion and late in the SOX drafting process, ${ }^{95}$ Section 402 did not address such obvious issues as travel advances, relocation and retention loans, and broker-assisted cashless stock-option exercises. Thus, Section 402 provides some support for Professor Romano's critique that post-crash reform legislation can be overbroad and can disrupt legitimate business practices and objectives. What she ignores, however, is that this provision did not last long.

Despite Professor Romano's views that executive loans were a matter of "settled state law" and did not generate "scholarly controversy," 96 the empirical evidence indicates that such loans resulted in stealth compensation and were associated with both higher rates of financial misstatement and lower industry-adjusted returns. ${ }^{97}$ Further, although Professor Romano defends executive loans as leading to greater stock ownership and better alignment of interests between corporate management and shareholders, several studies question this linkage, partly because the stock so acquired could be (and usually

94 Section 402 is codified in Section 13(k) of the Securities Exchange Act of 1934 ("Prohibition on Personal Loans to Executives"). See ch. 404, 48 Stat. 881 (codified as amended at 15 U.S.C. $\$ 78 \mathrm{~m}(\mathrm{k})(2006)$ ). The language of Section $13(\mathrm{k})$ is broad, because it precludes the issuer not only "to extend or maintain credit," but also "to arrange for the extension of credit, or to renew an extension of credit." See id.

95 As Professor Romano notes, Section 402 "was introduced at the end of the legislative process in the Senate as a floor amendment substitute for a provision" that was initially drafted "as a disclosure measure." See Romano, supra note 13, at 1538.

96 See id.

97 See Prentice \& Spence, supra note 8, 1894-95 (summarizing this evidence); see also Charles P. Cullinan et al., A Test of the Loan Prohibition of the Sarbanes-Oxley Act: Are Firms that Grant Loans to Executives More Likely to Misstate Their Financial Results?, 25 J. AcCT. \& PuB. PoL'y 485, 486 (2006) (examining "whether granting executive loans in the pre-SarbanesOxley period was associated with misstated financial statements"); Kathleen M. Kahle \& Kuldeep Shastri, Executive Loans, 39 J. Fin. \& Quantitative ANalysis 791, 794-95 (2004); Elizabeth A. Gordon et al., Related Party Transactions and Corporate Governance: Associations with Corporate Governance and Firm Value 5 (EFA 2004 Maastricht Meeting, Paper No. 4377) (Sept. 2004), available at http://papers.ssrn.com/sol3/papers.cfm?abstract_id=558983 (finding "strong negative relationship between industry-adjusted returns and loans" to executives). 
was) immediately sold. ${ }^{98}$ In any event, these executive loans induced managers to pursue high-risk corporate investment policies. ${ }^{99}$

Of course, what moved Congress to adopt SOX was not the empirical studies or the economic arguments, but the anecdotal evidence of extreme abuse: Bernie Ebbers, CEO of WorldCom, borrowed $\$ 408$ million from his company (and could ultimately repay none of it); Ken Lay, CEO of Enron, received $\$ 70$ million in loans from Enron (as opposed to only $\$ 67$ million in compensation); and Dennis Kozlowski, CEO of Tyco, borrowed approximately $\$ 270$ million (which he largely used to purchase personal assets and real estate, rather than stock). ${ }^{100}$ As of 2002 when Congress enacted SOX, the average cash loan disclosed by those public companies that disclosed loans to executives was $\$ 11$ million, and the total insider indebtedness for such companies was $\$ 4.5$ billion. ${ }^{101}$ Worse yet, only stock itself secured many of these executive loans; thus, if the company's stock price dropped, the board faced the choice of lending additional amounts to the executives or watching the borrowers sell their stock and drive down the company's stock price. ${ }^{102}$

The bottom line is that Congress had legitimate justifications for seeking to curb executive loans, but did so clumsily and in an overbroad fashion. What happened next? The real surprise in the aftermath to Section 402 is that the SEC did virtually nothing. Instead, a coalition of some 25 major law firms drafted and publicly released a memorandum explaining how they would interpret Section 402,103 and the SEC quietly acquiesced. ${ }^{104}$ Many of the positions taken in this memorandum were quite reasonable, while others were more questionable and almost certainly would not have been proposed in an SEC release. More important than the particular positions taken, however, is that the bar simply replaced the SEC as the authoritative interpreter of the statute's meaning. This example shows the Regulatory Sine Curve on steroids.

Why did the SEC behave so passively? One reason may be that state law governs the corporate power to make loans to executives, and the SEC felt uncomfortable invading Delaware's territory. Equally likely, however, is an alternative explanation: the SEC is a law-

\footnotetext{
98 See Prentice \& Spence, supra note 8, at 1893-94.

99 Gordon et al., supra note 97.

100 See id.

101 See Lucian Bebchuk \& Jesse Fried, Pay Without Performance: The Unfulfilled Promise of Executive Compensation 113-14 (2004).

102 See Prentice \& Spence, supra note 8, at 1894.

103 See Memorandum from Sullivan \& Cromwell LLP et al., Sarbanes-Oxley Act: Interpretive Issues Under \$ 402-Prohibition of Certain Insider Loans 1 (Oct. 15, 2002), available at http://www.adrbnymellon.com/files/climail4.pdf.

104 See Deborah Solomon, Sarbanes and Oxley Agree to Disagree, WALl St. J., Jul. 24, 2003, at $\mathrm{Cl}$.
} 
yer-dominated agency that does not want to confront the private bar's elite law firms. Once those firms took a collective position, the confrontation would have been personal and even bruising if the SEC rejected their interpretation. Here, one must consider the much discussed "revolving door" phenomenon under which SEC staffers join the Commission for a brief tour of duty before returning to positions on Wall Street or in the private bar. ${ }^{105}$ Given such career expectations, SEC staffers may be more anxious about confronting the bar than any other interest group.

Still, the result was that the SEC allowed the bar to dictate the interpretation of a statutory provision in a manner that closely circumscribed what Congress broadly, if clumsily, had forbidden. The result was that a legislative "thou shall not" was quietly converted into a much weaker administrative "thou generally should not." Interestingly, in the time since the SEC adopted the 25 law-firm memorandum, the SEC has-with one exception-not brought an enforcement proceeding to contest an executive loan. ${ }^{106}$ One suspects that such enforcement opportunities existed, if the SEC had wanted to pursue them.

\section{Attorneys as Whistle Blowers and Section 307}

Section 307 of SOX instructed the SEC to adopt minimum standards of professional conduct for attorneys appearing and practicing before the Commission in the representation of public companies. Congress enacted this provision with considerable fanfare, as a prominent Senator noted that lawyers were always present "at the scene of the crime" when securities frauds occurred. ${ }^{107}$ The Commission responded by adopting its "Standards of Professional Conduct for Attorneys Appearing and Practicing Before the Commission in the

105 See Sorkin, supra note 38.

106 The lone exception to this generalization is Goodfellow \& Molaris, Exchange Act Release No. 52,865, 2005 WL 3240602 (Dec. 1, 2005). In this case, the CFO of a public corporation authorized an interest-free loan to the CEO, and two weeks later the CEO approved a similar interest-free loan to the CFO. See $i d$. at $* 2$. The approval of the board of directors was never sought; nor was disclosure made to the board. See id. The absence of board approval plus officer acknowledgment of their awareness of the SOX prohibition on executive loans may explain why the SEC made an exception and sued in this case and not yet in others.

107 See 148 Conc. Rec. S6556 (daily ed. Jul. 10, 2002) (statement of Sen. Corzine). Reviewing Enron, WorldCom and other recent scandals, Senator Enzi, cosponsor of Section 307 , told the Senate, "one of the thoughts that occurred to me was that probably in almost every transaction there was a lawyer who drew up the documents involved in that procedure." 148 Cong. Rec. S6554 (daily ed. Jul. 10, 2002) (statement of Sen. Enzi). For a fuller discussion of Section 307 and the debate over it, see generally John C. Coffee, Jr., The Attorney As Gatekeeper: An Agenda for the SEC, 103 Colum. L. REv. 1293 (2003). 
Representation of an Issuer" with even greater fanfare in 2003.108 Under it, attorneys have an obligation to report material violations of federal or state securities laws and breaches of fiduciary duty to the issuer's chief legal officer or to its chief executive officer. ${ }^{109}$ If the issuer still fails to take action, the Commission may require the lawyer to report further the violation to the company's audit committee. ${ }^{110}$ Under some limited circumstances, the lawyer is permitted, but not required, to disclose a material violation directly to the SEC. ${ }^{111}$

Total silence on the enforcement front has followed the SEC's aspirational Standards of Professional Conduct. Despite numerous instances in which lawyers were clearly aware of executive misconductand both the stock-option backdating scandal and the mutual-fundmarket timing scandal followed the adoption of these standards and presented instances in which misconduct involving violations of the federal securities laws deeply implicated attorneys-the SEC appears to date never to have charged an attorney representing a public corporation with violating this rule. To be sure, lawyers have been indicted for securities fraud and insider trading and civilly sued by the SEC, but these cases usually involve egregious self-dealing. ${ }^{12}$ The SEC simply has not used the lesser remedy of asserting a professional conduct violation.

Why not? Sanctioning attorneys for failure to report violations up the ladder within the corporate structure would again place the SEC in a position of high conflict with the bar. In contrast to prosecutions of attorneys for insider trading or other scienter-based offenses, the SEC's enforcement of reporting rules would reach attorneys who acted only negligently or who declined to act, in either case without any clear element of self-dealing.

108 See 17 C.F.R. $\$ \S 205.1-205.7$ (2011); see also Implementation of Standards of Professional Conduct for Attorneys, Securities Act Release No. 8185, Exchange Act Release No. 47,276, Investment Company Act Release No. 25,919, 68 Fed. Reg. 6296 (Feb. 6, 2003). Although the Commission adopted its "up-the-ladder" reporting requirement of evidence of material violations of law, it abandoned, under pressure from the American Bar Association, its original proposal that the attorney resign and report to the SEC when a corporate client refuses to rectify a material violation of law. See Implementation of Standards of Professional Conduct for Attorneys, Securities Act Release No. 8186, Exchange Act Release No. 47,282, Investment Company Act Release No. 25,920, 68 Fed. Reg. 6324 (Feb. 6, 2003).

109 Rule 3 ("Issuer as Client") requires an attorney appearing and practicing before the Commission in the representation of an issuer who "becomes aware of evidence of a material violation by the issuer or by any officer, director, employee or agent of the issuer" to "report such evidence to the issuer's chief legal officer . . forthwith." See 17 C.F.R. $\S 205.3$.

110 See 17 C.F.R. $\S 205.3(\mathrm{~b})(3)$ (i).

111 See 17 C.F.R. $\$ 205.3$ (d) (2).

112 See, e.g., Litigation Release No. 21541, SEC v. Starr, U.S. Sec. \& Exch. Сомм'N. (June 1, 2010), http://www.sec.gov/litigation/litreleases/2010/lr21541.htm (suing an attorney for misappropriating approximately $\$ 7$ million in client funds). 
The SEC has long (and perhaps unwisely) resisted entering this zone, based on the overbroad rationale that to discipline attorneys for negligence or inaction would chill the attorney-client relationship and might dissuade clients from seeking legal advice. ${ }^{113}$ A recent case exemplifies the SEC's continuing reluctance to engage in nonscienterbased enforcement actions against attorneys. In Monson, ${ }^{114}$ SEC staff brought a cease and desist proceeding against a general counsel of a publicly held broker-dealer who allegedly facilitated late trading by that broker-dealer on behalf of its clients in over 600 mutual funds in violation of a very explicit and well-known Investment Company Act rule. ${ }^{115}$ The attorney drafted an agreement that authorized the broker-dealer's clients to engage in "late trading," but the SEC staff did not allege that the attorney either knew that late trading violated the securities laws or that the clients had engaged in late trading. ${ }^{116}$ Noting that it long avoided bringing cases against an attorney on the theory that the attorney "departed from professional standards of competence in rendering private legal advice to their clients," 117 the Commission explained that such restraint was necessary to avoid "encroachment by the Commission on regulation of attorney conduct historically performed by the states." 118

Arguably, these concerns are overblown when applied to an attorney who drafts an agreement expressly authorizing unlawful conduct.

113 For a brief period, the SEC ruled that a securities attorney was, under some circumstances, obligated to advise the board if the attorney became aware that the corporation was violating a federal securities laws. This position still fell far short of a "whistle blowing" obligation and only recognized that the issuer was the client. See Carter \& Johnson, Exchange Act Release No. 17,596, 22 SEC Docket 292 (Feb. 28, 1981). Still, it did recognize a professional obligation for the attorney sometimes to go to the board. Later, however, the Commission retreated from this position. See Disciplinary Proceedings Involving Professionals Appearing or Practicing Before the Commission, Securities Act Release No. 6783, Exchange Act Release No. 25,893, Investment Company Act Release No. 24,676, 41 SEC Docket 388, 395 n.31 (Jul. 7, 1988) (noting that "[s]ince Carter and Johnson, the Commission has not attempted to set professional standards of conduct in Rule 2(e) proceedings, but has relief on a showing of violations of the securities laws"). Section 307 of the DoddFrank Act imposed a Carter and Johnson-like standard on the SEC, which is, so far, not enforced.

114 Investment Company Act Release No, 28,323, In the Matter of Scott G. Monson, Admin. Proc. File No. 3-12429, 2008 SEC LEXIS 1503, at *1-2 (June 30, 2008) [hereinafter Monson].

115 See 17 C.F.R. § 270.22c-1.

116 See Monson, supra note 114 , at $* 2$.

117 Id. at $* 17$.

$118 I d$. at $* 18$ (internal footnotes omitted). This decision added that it was motivated by the desire to avoid "interference with lawyers' ability to provide unbiased, independent legal advice regarding the securities laws." Id. Procedurally, the Commission affirmed the dismissal of the Enforcement Division's complaint on grounds unrelated to the above arguments about interfering with independent legal advice, citing insufficient evidence that the attorney had in fact acted negligently. See id. at*18-22. Still, the decision stands, and has been read, as a signal that the Commission did not wish to go further into this area. 
Late trading is not a gray offense. More importantly, such an explanation-that the Commission will not normally proceed against professionals absent evidence of scienter-implies that the Commission will not seriously enforce Section 307. Thus, it should not be surprising that the Commission has seemingly abandoned Section 307. As with its refusal to enforce the executive loan prohibition, the Commission is unwilling to enter areas where it might either infringe on state regulation or encounter resistance from the bar. In so doing, the Commission's passivity undercuts or abandons clear Congressional pronouncements. Curiously, its rationale is the same as that advocated by critics such as Professors Romano and Bainbridge: that federal agencies should not "encroach" upon areas traditionally relegated to state regulation.

Possibly, this explanation for equivocal SEC enforcement in the case of the financial industry is too narrow. Some federal courts have expressed concern that symbolic but hollow victories too easily satisfy the SEC, which is too apprehensive about the prospect of a litigation defeat to take on a major opponent. That was the thrust of Judge Rakoff's recent Bank of America decision. ${ }^{119}$ For present purposes, it is unnecessary to select the best explanation to reach the conclusion that equivocal SEC enforcement in cases involving major players in the financial industry has long been the pattern, and that pattern seems unlikely to change markedly in the near future.

\section{An Evaluation}

The Tea Party critics of both SOX and the Dodd-Frank Act argue that, because Congress hastily frames reform legislation, "[s] uspect [p]olicy [e]ntrepreneurs" thereby "hijack the legislative process to advance a long-standing political agenda" and in so doing distort policy formulation. ${ }^{120}$ Brief as it is, this review of SOX should clarify that suspect policy entrepreneurs did not play a major role in adopting or expanding SOX's most controversial provision, Section 404. Nor is the meaning of "suspect policy entrepreneur" analytically clear or helpful. Many interest groups, including particularly business interest groups, attempt to influence legislation and regulation. Critics do not

119 See SEC v. Bank of Am. Corp., 653 F. Supp. 2d 507, 512 (S.D.N.Y. 2009). The court ultimately approved a revised settlement. See SEC v. Bank of Am. Corp., Nos. 09 Civ. 6829(JSR), 10 Civ. 0215(JSR), 2010 WL 624581, at *6 (S.D.N.Y. Feb. 22 2010). More recently, Judge Rakoff questioned the SEC's long-standing policy permitting defendants to neither admit nor deny its allegations and settle the case without their resolution. See SEC v. Citigroup Global Mkts. Inc., No. 11 Civ. 7387(JSR), 2011 WL 5903733, at *2 (S.D.N.Y. Nov. $28,2011)$ (declining to approve proposed settlement). This decision is on appeal and the issues in the case are beyond the scope of this Article.

120 See Bainbridge, supra note 21, at 1815-16 (describing the Dodd-Frank Act drafting). 
adequately explain why investor-oriented groups, such as public pension funds, are "suspect," while groups favoring the status quo, such as business interest groups, are not considered equally suspect.

As next explained, this critique has been similarly directed at the Dodd-Frank Act. ${ }^{121}$ Once again, however, this critique has only limited explanatory power. Even if investor-oriented groups are more politically active in the period following a crash, it remains unclear why their activity is suspect, as opposed to the better-funded political activity of business interest groups in seeking to repeal or curtail such legislation after normalcy returns.

\section{III}

\section{The Dodd-Frank Act: Premises and Policy Options}

In 2008, Congress saw the nation's largest financial institutions race like lemmings over the cliff and into insolvency. Why did they all become insolvent at once? A variety of commentators have offered basically three credible scenarios. Each seems correct in part, and each motivated the legislative effort that produced the Dodd-Frank Act.

\section{A. Moral Hazard: "Executive Compensation Caused the Crash"}

Because a rapid shift towards incentive-based compensation at financial institutions focused senior management on short-term results, longer-term risks were ignored or excessively discounted. ${ }^{122}$ For example, if the executives in charge of asset-backed securitizations at a financial institution could make $\$ 100$ million in bonuses in a single year if sufficient deals closed that year, such expected compensation could easily produce a "damn-the-torpedoes, full-speed-ahead" approach to risk taking. Indeed, why should executives so compensated worry at all about the longer-term risks to their bank? Thus, excessive compensation led to moral hazard. Inevitably, such a diagnosis leads to proposals to restrict executive compensation. But how and by whom? Here, the devil is in the details. Once we descend into the details in the implementation process, the special-interest groups and their lobbyists hold all the advantages.

\footnotetext{
121 See id. at 1815-20.

122 For the fullest statement that executive compensation, particularly incentive compensation, gave rise to a moral-hazard problem, see Lucian A. Bebchuk \& Holger Spamann, Regulating Bankers' Pay, 98 GEo. L.J. 247, 255-74 (2010); Lucian A. Bebchuk et. al., The Wages of Failure: Executive Compensation at Bear Stearns and Lehman 2000-2008, 27 YALE J. ON REG. 257, 273-76 (2010).
} 
B. Because Creditors Believed That "Too Big to Fail" (TBTF) Banks Would Always Be Bailed Out, They Advanced Funds Too Cheaply and Encouraged Banks to Become Overleveraged

Economists generally agree that an implicit governmental subsidy for TBTF banks arose because the market assumed that the government would bail out such institutions. ${ }^{123}$ Such an implicit guarantee of their solvency leads investors to lend more cheaply to TBTF banks in comparison to smaller banks. ${ }^{124}$ The larger the bank, the cheaper it could borrow, in part because all assumed that the government would not allow the bank to fail. Seeing this subsidy, the shareholders and managers of such financial institutions rationally exploited it by taking on excessive debt and leverage. ${ }^{125}$ In effect, this subsidy encouraged the TBTF banks to risk a solvency crisis because all market participants believed that the government would have to bail them out. From this perspective, the core evil is the implicit subsidy for TBTF banks through cheaper borrowing costs. The obvious economic answer is to tax this externality and cancel the subsidy. But eliminating subsidies and taxing externalities means making banks less profitable, and every possible level of the industry will predictably fight any such program-usually with the politically potent counterargument that imposing higher costs on TBTF banks will reduce employment and lending.

C. Bounded Rationality: Cognitive Limitations, Conflicts of Interest, and a Lack of Transparency Induced Market Participants to Repress Recognition of the Problems Overtaking the Market

AIG provides the paradigm of this problem. ${ }^{126}$ By 2008, most major financial institutions relied, directly or indirectly, on credit default swaps issued or backstopped by AIG to hedge these institutions' expo-

123 For an aggressive statement of this view, see Anat R. Admati et al., Fallacies, Irrelevant Facts, and Myths in the Discussion of Capital Regulation: Why Bank Equity Is Not Expensive 1-7 (Rock Ctr. for Corporate Governance at Stanford Univ., Working Paper No. 86, 2010), available at https://gsbapps.stanford.edu/researchpapers/library/RP2065R1\&86.pdf.

124 See John C. Coffee, Jr., Systemic Risk After Dodd-Frank: Contingent Capital and the Need for Regulatory Strategies Beyond Oversight, 111 Colum. L. Rev. 795, 800-01 (2011).

125 See id. at 798-99.

126 For representative critiques from this perspective of bounded rationality, see CARmen M. Reinhart \& Kenneth S. Rogoff, This Time is Different: Eight Centuries of Financial Folly xxxix-xlv (2009); Gary Gorton, The Subprime Panic, 15 Eur. Fin. Mgmt. 10, 36-37 (2009); Donald C. Langevoort, Chasing the Greased Pig Down Wall Street: A Gatekeeper's Guide to the Psychology, Culture, and Ethics of Financial Risk Taking, 96 CoRnell L. REv. 1209, 1242 (2011). 
sure to financial risks. ${ }^{127}$ Public recognition of AIG's aggregate contingent liability on credit default swaps would have revealed AIG's inability to insure these institutions against an exposure of this magnitude. Instead, even if the market's extraordinary dependence on AIG was dimly perceived, market participants were not forced to admit that the Emperor had no clothes. Rather, the problem was collectively repressed, which occurred to a considerable degree because the credit default swap market was itself opaque. Often for self-interested reasons, again involving executive compensation, financial managers continued to maintain highly vulnerable portfolios and remained exposed to enormous risk, relying on an illusory form of insurance.

So what is the appropriate answer to correct this recurring tendency? If a stubborn refusal to recognize inconvenient truths is the problem, the obvious policy reform is greater transparency: require OTC derivatives to be traded over exchanges and through clearinghouses, and it will become less possible for one actor to assume AIG's position as the counterparty for the entire market. As will be seen, the Dodd-Frank Act moves in this direction-equivocally and in a manner dependent on pending implementation.

In response to all these perceived causes of the 2008 crisis, the Dodd-Frank Act pursued several strategies, broadly delegating authority to administrative agencies to fill in the details. First, in response to the initial hypothesis that excessive compensation induced excessive risk-taking, the Dodd-Frank Act adopted two somewhat inconsistent strategies. On one hand, it sided with traditional corporate governance reformers, enacting much of their standard agenda to enhance shareholder power: access to the proxy statement, "say-on-pay" advisory shareholder votes, and the elimination of broker votes. ${ }^{128}$ On the other hand, the Dodd-Frank Act gave financial regulators broad paternalistic power to restrict executive compensation. ${ }^{129}$ As will be seen, with the return of "normalcy," courts have struck down some of the corporate governance reforms and others reforms are in jeopardy. ${ }^{130}$

127 By the end of 2007 , AIG had sold credit default swaps with a notional amount of roughly $\$ 527$ billion, of which $\$ 61.4$ billion referenced collateralized debt obligations holding mortgage-backed securities as collateral. See Michael Lewis, The Big Short: Inside THE Doomsday Machine 197 (2010); Am. Int'l Grp., Inc., Annual Report (Form 10-K) at 122 (Feb. 28, 2008).

128 See Dodd-Frank Wall Street Reform and Consumer Protection Act (Dodd-Frank Act), Pub. L. No. 111-203, §§ 951, 957, 971, 124 Stat. 1376, 1899-1900, 1906-07, 1915 (2010) (codified at 15 U.S.C. $\$ 78 \mathrm{n}-1$ (Supp. IV 2010)).

129 See id. \$956; infra notes 209-25 and accompanying text.

130 See Business Roundtable v. SEC, 647 F.3d 1144, 1148-56 (D.C. Cir. 2011) (invalidating SEC's proxy access rule, which the Commission adopted pursuant to Section 971 of the Dodd-Frank Act); infra notes 202-07 and accompanying text. 
Meanwhile, regulators are quietly downsizing the Dodd-Frank Act executive compensation restrictions. ${ }^{131}$

With respect to this second diagnosis that the TBTF bank subsidy induced the excessive leverage that underlay the 2008 crisis, the Dodd-Frank Act took elaborate steps to restrict federal lending to large financial institutions, unless the institution was first placed into liquidation. The Dodd-Frank Act aimed to signal that there would be no more bailouts, and hence creditors should not lend to TBTF banks on the same discounted terms. Yet, liquidity crises are endemic to banking, and whether the Dodd-Frank Act resolves or aggravates the "TBTF problem" is debatable. All that is clear is that, post-2008, the U.S. banking industry has become even more consolidated (as the survivors acquired those institutions that failed), and the failure of a TBTF bank would be even more catastrophic. Perhaps, as many suspect, financial regulators can still outflank the Dodd-Frank Act's restrictions and find ways to bail out a failing bank. But, if so, the implicit subsidy has not been ended and the potential for another systemic risk crisis remains latent beneath the surface of reform.

Finally, looking at the AIG paradigm, Congress decided to shift the trading of OTC derivatives to exchanges and require the use of clearinghouses, but stopped short of deciding how far to push this reform and instead delegated the issue, subject to some substantial exemptions, to financial regulators. ${ }^{132}$

This Article does not portray the Dodd-Frank Act as perfect legislation. Like much reform legislation, it is a potpourri of different provisions, some of which may be inconsistent or poorly conceived. This is inevitable in the real world where Congress must act under time pressure and faces the need to satisfy many constituencies. Thus, this Article focuses more on the incompleteness of the Dodd-Frank Act, the continuing need for detailed implementation, and the erosive impact of the Regulatory Sine Curve on that process. It will focus primarily on three areas: (1) executive compensation, (2) the TBTF problem and proposed reforms to restrain risk-taking by TBTF banks, and (3) the OTC derivatives area-where the AIG bailout motivated Congress to act. Although this Article agrees, in some respects, that Congress imperfectly designed the Dodd-Frank Act, the greater problem is that the Act relies excessively on administrative implementation that is too easily frustrated or judicially overturned.

131 See infra notes 209-25 and accompanying text.

132 See Dodd-Frank Act $\$ \$ 721-754$ (codified as amended in scattered sections of 7 and 15 U.S.C.) ("Regulation of Swap Markets"). 


\section{Executive Compensation and Shareholder Pressure}

The conventional story of the 2008 crisis-as best told by Professor Lucian Bebchuk and his coauthors-focuses on the perverse influences executive-compensation formulas create. ${ }^{133}$ They argue not only that executive pay packages focused excessively on short-term results, but that because senior executives' compensation packages were closely tied to highly leveraged bets on the value of the banks' assets, such executives shared in any shareholder gains but were insulated from shareholder losses. ${ }^{134}$ In short, executives could focus on the upside and ignore the downside of any risky strategy. The result, Bebchuk and his coauthors argue, is a classic moral-hazard problem. ${ }^{135}$

To corroborate their claim, Bebchuk and his coauthors collected data showing that senior managers profited handsomely even when shareholders lost virtually everything. Examining the failures of Bear Stearns and Lehman, they found that the top five executives at each firm cashed out extraordinary amounts of performance-based compensation during the 2000-2008 period. ${ }^{136}$ Specifically, they estimate that these top five management teams derived $\$ 1.4$ billion and $\$ 1$ billion, respectively, from cash bonuses and equity sales during this period. ${ }^{137}$ These amounts substantially exceeded the same executives' stock holdings at the beginning of the period. ${ }^{138}$ If managers win when shareholders lose, this finding supports the moral-hazard diagnosis of Bebchuk and his coauthors.

Their research has not, however, gone unchallenged. In particular, René Stulz coauthored several papers that dispute this thesis that the executive compensation formulas for senior executives at financial institutions drove the 2008 crisis by creating an incentive to accept excessive risk. ${ }^{139}$ In one paper, Stulz and a coauthor found evidence that those banks with chief executive officers (CEOs) whose incentives were better aligned with their shareholders actually performed worse

133 See generally Bebchuk \& Spamann, supra note 122; Bebchuk et al., supra note 122 (framing the crisis as a consequence of misaligned incentives and moral hazard).

134 See Bebchuk \& Spamann, supra note 122, at 249-50.

135 See id. at 257-64.

136 See Bebchuk et al., supra note 122, at 257.

137 See id. at 271.

138 See id. at 271-72.

139 See Rüdiger Fahlenbrach \& René M. Stulz, Bank CEO Incentives and the Credit Crisis, 99 J. Fin. Econ. 11, 11-13 (2011); Andrea Beltratti \& René M. Stulz, Why Did Some Banks Perform Better During the Credit Crisis? A Cross-Country Study of the Impact of Governance and Regulation 2-4 (European Corporate Governance Inst., Finance Working Paper No. 254/ 2009, 2009), available at http://papers.ssrn.com/sol3/papers.cfm?abstract_id=1433502. 
during the crisis. ${ }^{140}$ They suggest that, "CEOs with better incentives to maximize shareholder wealth took risks that other CEOs did not."141 Nor do they find that bank CEOs reduced their stock holdings prior to 2008; hence, CEOs suffered large wealth losses along with the shareholders. ${ }^{142}$ In short, little evidence supports the claim that CEOs overreached their shareholders.

In another study, Stulz and a coauthor found that banks with "shareholder-friendly" corporate governance performed worse during the 2008 crisis. ${ }^{143}$ Indeed, banks that the market favored in 2006 had especially poor returns during the crisis. ${ }^{144}$ In other words, financial institutions that led the market in 2006 encountered disaster in 2008. In contrast, financial institutions that were stodgy and unresponsive to shareholder desires in 2006 experienced the least losses in 2008.145 Such findings are at least consistent with the view that shareholder pressure led managers to take on higher leverage and accept greater risk in the boom years - with catastrophic consequences later in 2008. In effect, shareholders pushed TBTF banks onto a financial roller coaster, and the firms they controlled soared to record peaks and plunged to deep valleys in rapid succession.

Other studies by different teams of researchers reach similar conclusions. Gropp and Köhler found that "owner-controlled" banks had higher profits in the years before the 2008 crisis in comparison to "manager-controlled" banks, but experienced larger losses and were more likely to require governmental assistance during the 2008 crisis. ${ }^{146}$ Using a sample of 296 firms from thirty countries, Erkens, Hung, and Matos show that firms with more independent boards and higher institutional ownership experienced worse stock returns during the 2007-2008 crisis. ${ }^{147}$ Specifically, they found that firms with higher institutional ownership took "greater risk in their investment

140 See Fahlenbrach \& Stulz, supra note 139, at 12 (arguing that the most plausible explanation for these findings is that CEOs "took actions that they believed the market would welcome," but "[e]x post, these actions were costly to their banks").

141 See id. at 25.

142 See id. at 12-13.

143 See Beltratti \& Stulz, supra note 139, at 3.

144 See id. at 2. Banks that performed in the lowest quartile during the 2008 crisis averaged returns of $-87.44 \%$ during the crisis with pre-crisis 2006 averaged return of $+33.07 \%$. See id. at 14 .

145 The crisis' highest performing banks averaged returns of $-16.58 \%$ during the crisis, with average returns of $+7.80 \%$ in 2006 . See id. at 14 .

146 See Reint Gropp \& Matthias Kōhler, Bank Owners or Bank Managers: Who is Keen on Risk? Evidence from the Financial Crisis 21 (European Bus. Sch., Research Paper No. 10-02, 2010), available at http://papers.ssrn.com/sol3/papers.cfm?abstract_id=1555663.

147 See David H. Erkens, Mingyi Hung \& Pedro Matos, Corporate Governance in the 2007-2008 Financial Crisis: Evidence from Financial Institutions Worldwide, 18 J. CoRP. FIN. 389, 390 (2012). 
policies before the onset of the crisis."148 Such evidence suggests that even if managers prefer to avoid high risk and leverage, shareholders' preferences override. In particular, institutional investors can compel firms to accept greater risk and thus cause the firm to suffer increased losses in a crisis.

The point here is not that Professor Bebchuk and his coauthors are wrong. They argue that the pay formulas used to compensate senior management at banks gave them an excessive incentive to accept risk. ${ }^{149}$ But such an increased incentive could be exactly what shareholders wanted. Shareholders have long used executive compensation to align managerial preferences with their own, and institutional investors certainly understand that managers are undiversified and thus risk averse about corporate insolvency. Being diversified and having limited liability, shareholders do not suffer as much as managers from a bankruptcy. To "correct" the managerial tendency toward risk aversion, shareholders might have been willing to accept even imperfect compensation formulas to seduce managers into accepting increased risk. Thus, both sides in this debate could have valid points. Bebchuk and company appear correct in arguing that compensation formulas create excessive incentives for bank managers to engage in risky activities, and Stulz and others can legitimately interpret their own data to mean that shareholder-controlled firms accept higher risk and hence are more prone to failure in a crisis than firms in which managers are free to enjoy the quiet life (and so avoid risk). Rather than managers overreaching shareholders, it looks instead as if these compensation formulas roughly aligned managerial and shareholder interests, but created a socially excessive incentive for risk-taking. Under this synthesis, shareholders, as principals, simply found ways to contract with their agent managers to accept greater risk through lucrative compensation formulas.

But that only brings us back to the centrality of shareholder pressure and the gap in bank governance between what is privately and socially optimal. Arguably, shareholders of financial institutions accepted high leverage and risk, not simply because they were diversified, but because they believed that (1) major banks were too big to fail, and (2) the implicit reduction in interest expense charged to TBTF banks created an opportunity for cheap capital that could not be spurned. Based on these expectations, shareholders of major financial institutions could rationally pressure management to accept more risk than shareholders might consider advisable at industrial corporations.

\footnotetext{
148 See id.

149 See Bebchuk et al., supra note 122, at 264-65.
} 
At this point, it is necessary to disaggregate shareholders. Individual shareholders may sometimes also be risk averse and disinclined to pressure management toward greater risk and leverage, but they are a decreasing minority of all shareholders. ${ }^{150}$ Yet, not only do institutional investors own a majority of the equity in U.S. public corporations, but institutional investors' level of ownership rises to $73 \%$ when we focus on the top 1,000 U.S. corporations-among which large financial institutions easily rank. ${ }^{151}$ In terms of equity holdings, mutual funds now represent the largest category of institutional owner. ${ }^{152}$ Their high level of ownership is important because, in comparison to pension funds, mutual funds more actively compete for the investor's favor, and their recent investment returns will likely heavily influence this competition. In particular, hedge funds compete aggressively for investors' funds and tend to be the most proactive investors.

Historically, pension funds were largely indexed investors, holding large portfolios that mimicked the broader market. Thus, they were disinclined to become involved in individual corporate governance disputes, because they could not profit significantly from them. ${ }^{153}$ But this is changing. Increasingly, pension funds are investing their stock portfolios in hedge funds to obtain returns superior to simple indexing. ${ }^{154}$ In turn, these hedge funds pursue proactive strategies, and one of their favorite targets is the underleveraged firm. ${ }^{155}$

The equity investors' preference for leverage is, in turn, complemented by debt investors' continuing expectation that the government will protect them in federally-assisted rescue of a failing financial institution. When faced with a failing bank, the federal government

150 Recent estimates find retail or individual shareholders own only roughly $25 \%$ of the publicly traded stock, with the remainder owned by both domestic and foreign institutional investors. See Alan R. Palmiter, Staying Public: Institutional Investors in U.S. Capital Markets, 3 Brook. J. Corp. Fin. \& Com. L. 245, 262 tbl.1 (2009). Since 2001, institutional investors have held over $50 \%$ of the total outstanding equity in U.S. public corporations. See Tonello \& Rabimov, supra note 49, at 22 tbl.10.

151 See Tonello \& Rabimov, supra note 49, at 27 chart 14 (showing this percentage as $76.4 \%$ in 2007 and $73 \%$ in 2009 ).

152 See id. at 24, 25-26 tbl.12 (showing mutual funds held $20.9 \%$ of the total U.S. equity market in 2009, slightly more than aggregated pension funds).

153 For the standard observation that many institutional investors hold too large a portfolio to take interest in firm-specific corporate governance, see, e.g., Robert Cyran, Beware: Activists Are on the Hunt, N.Y. Times, Mar. 4, 2010, at B2.

154 See Coffee, supra note 124, at 812 n.54; Christine Williamson, Big Public Funds Outperform Their Hedge Fund Yardsticks, Pensions \& Investments, Sept. 20, 2010, at 1 (noting that the $\$ 205.5$ billion California Public Employees' Retirement System (CalPERS) invested in hedge funds in 2002 and since "moved the majority of its portfolio into direct investments in single and multistrategy hedge funds"). A number of other state pension funds followed CalPERS in this shift. See id.

155 Typically, such an activist shareholder targets an underperforming firm "with a pristine balance sheet." See Cyran, supra note 153 . Often, the activist shareholder proposes the sale of assets and a special dividend of the proceeds, which also raises leverage. See id. 
traditionally arranged shotgun marriages through mergers-with federal assumption of at least some of the failing firm's liabilities. ${ }^{156}$ This was the strategy followed to rescue Bear Stearns, Merrill Lynch, and Wachovia during the 2008 crisis. ${ }^{157}$ Under this standard pattern, even if the government did not protect shareholders of the failed bank, it protected its creditors. Thus, the implicit subsidy in interest rates survives and should logically continue to motivate shareholders to seek to exploit cheap financing at the cost of excessive leverage.

From this perspective, it seems ironically counterproductive that the Dodd-Frank Act actually sought to reform corporate governance to enhance the shareholders' ability to pressure managers, because such shareholder pressure would predictably often seek to compel managers to increase leverage and accept greater risk. Nonetheless, the Dodd-Frank Act authorized the SEC to give dissident shareholders "access to the proxy statement," which meant enabling them to mount low-cost campaigns for minority seats on the board without undertaking their own, more costly proxy solicitations. ${ }^{158}$ The SEC responded to this invitation by quickly adopting Rule 14a-11, which authorized dissident shareholders to place their nominees on the corporation's proxy statement. ${ }^{159}$ Rule $14 \mathrm{a}-11$ could be a desirable counterweight to entrenched managerial power in much of corporate America, but

156 Confronted with an approaching bank failure, the FDIC's preferred strategy has long been to arrange a "purchase and assumption" transaction with another bank-in effect, a shotgun marriage aided by the FDIC's assumption of some of the failed bank's liabilities. See Jonathan R. Macey \& Geoffrey P. Miller, Bank Failures, Risk Monitoring, and the Market for Bank Control, 88 Colum. L. REv. 1153, 1182-83 (1988). In the standard "purchase and assumption" transaction, "the deposits of the failed bank are assumed by another bank, which also purchases some of the failed bank's assets." See id. at 1182.

157 See, e.g., Robin Sidel et al., J.P. Morgan Buys Bear in Fire Sale, As Fed Widens Credit to Avert Crisis, WALL ST. J., Mar. 17, 2008, at A1.

158 Section 971 ("Proxy Access") of the Dodd-Frank Act added a new $\S 14$ (a) (2) to the Securities Exchange Act of 1934 that authorizes the SEC to adopt rules under which dissident shareholders may nominate candidates for the board of directors of a public company and include their nominees in the issuer's own proxy statement, thereby permitting these insurgents to economize on the costs of conducting a proxy fight. See Dodd-Frank Wall Street Reform and Consumer Protection Act, Pub. L. No. 111-203, § 971, 124 Stat. 1376, 1915 (2010) (codified at 15 U.S.C. $\$ 78$ n (Supp. IV 2010)).

159 See Facilitating Shareholder Director Nominations, Securities Act Release No. 9136, Exchange Act Release No. 62,764, Investment Company Act Release No. 29,384, 75 Fed. Reg. 56,668 (Sept. 16, 2010). Specifically, if certain conditions are satisfied, the new rule permits shareholders holding $3 \%$ or more of the corporation's voting power for a threeyear holding period to nominate candidates to fill to the greater of (1) $25 \%$ of the director positions to be elected, or (2) one director. See id. at 56,674-75. These alternative candidates would run against those nominated by the board's nominating committee. See id. at 56,761. Effectively, this procedure would spare the insurgents much of the costs of a proxy contest. See id. (noting that shareholders may prefer to use the new rules instead of launching "a costly traditional proxy contest").

The business community challenged the SEC's new "proxy access" rule and invalidated it in court. See Business Roundtable v. SEC, 647 F.3d 1144, 1148-49 (D.C. Cir. 2011) (invalidating Rule 14a-11 for failure to "adequately . . . assess the economic effects" of the 
financial institutions are a special case. Given the natural tension between the social interest in prudent bank regulation and the shareholder interest in profit maximization through higher leverage, corporate-governance reforms that enhanced shareholder power may simultaneously weaken regulatory control over financial institutions.

It is arguable that Rule 14a-11 would have had little impact. Close students of the proxy rules doubted that the "proxy access rule" would significantly alter the corporate-governance landscape or that the most powerful activists, like hedge funds, would have used it. ${ }^{160}$ More important than this rule was the reaction to it, which will be discussed shortly, because it shows the intensity with which the Regulatory Sine Curve can shift.

In fairness to Congress, the Dodd-Frank Act did not rely exclusively on corporate-governance reforms to restrict executive compensation. Rather than depending on the fox to guard the executivecompensation henhouse, Congress also enacted the very paternalistic Section 956 of the Dodd-Frank Act, which authorized regulators to prohibit excessive incentive-based compensation at "covered financial institutions" that "could lead to material financial loss to the covered financial institution." 161 This was a more direct route to reform, but, as also will be seen, financial regulators have already backed away from implementing Section 956 effectively. ${ }^{162}$

\section{Systemic Risk and the "Too Big to Fail" Problem}

The overriding goal of the Dodd-Frank Act was to reduce systemic risk. But dealing with systemic risk requires that we first understand it. Although there is no universally accepted definition of the term, ${ }^{163}$ most agree that it has three faces:

rule); infra notes 202-07 and accompanying text (discussing the impact of this case and assessing the weapon it gives business interests to challenge reform legislation).

160 See, e.g., Marcel Kahan \& Edward Rock, The Insignificance of Proxy Access, 97 VA. L. Rev. 1347, 1352, 1426-31 (2011). Under Rule 14a-11, activists who wish to use the rule must disclaim any intent to seek control. See Securities Act Release No. 9136, supra note 159. Hedge funds may often be unwilling to do this, as they wish to create at least the appearance of an impending control battle to boost the target's stock price. Also, the cost savings offered to them by the rule are insignificant where they would need to invest billions to acquire a significant position in a large financial institution.

161 See Dodd-Frank Act $\$ 956$ (a) (1). Dodd-Frank Act Section 956 also requires covered financial institutions to disclose "the structures of all incentive-based compensation" in order to enable the regulator to preclude excessive compensation. See id.

162 See infra notes 208-17 and accompanying text.

163 For a fuller definition of the term, see Steven L. Schwarcz, Systemic Risk, 97 GEO. L.J. 193,204 (2008). 
(1) A financial institution can simply be "too big to fail."164 Citigroup probably is, but Lehman was perceived not to be.

(2) An institution can be too connected to fail, largely a result of the increased use of OTC derivatives, including credit default swaps. ${ }^{165}$ As a result, the failure of one can imply the eventual failure of its counterparties in a cascade of falling financial dominoes. This scenario explains the government's bailout of AIG, upon whom all other major financial institutions relied on for protection. ${ }^{166}$

(3) Financial institutions can also be too risk-correlated to fail, with the result that the failure of one implies intense stress on the others. Although policies such as diversification can manage uncorrelated risk, risks that are correlated cannot be similarly resolved or protected against. ${ }^{167}$

This last face of systemic risk-risk correlation-is probably the least understood and most dangerous. Because of market pressures (fueled again in part by shareholders willing to accept risk), large financial institutions are inclined to adopt similar investment and strategic policies-or face a stock market penalty for their refusal. Thus, in the late 1990s, large financial institutions began aggressively to develop their asset-backed securitization business, because it appeared to offer the highest return on their capital. Assume next that one such institution encounters a liquidity crisis, as Bear Stearns did in early 2008, and must sell illiquid assets, such as interests in asset-backed securitizations, into a thin market. Prices fall quickly throughout this market, and other financial institutions may be forced to write down their investments or liquidate their investments in similar assets, or both. Moreover, short sellers and others realize that trouble at one financial institution signals distress at other similar institutions, and they compound the market pressure. The crisis then feeds on itself, as these banks begin to sell the same, now disfavored, investments into an even thinner market.

How can one design an intelligent policy that reduces systemic risk, given the likelihood that market and shareholder pressures will lead financial institutions to follow the herd and pursue similar invest-

164 For more on financial institutions that are "too big to fail," see generally Marcelo Dabós, Too Big to Fail in the Banking Industry: A Survey, in Too Bic to Fail: Policies and Practices in Government Bailouts 141 (Benton E. Gup ed., 2004).

165 See Schwarcz, supra note 163, at 202-04 (describing how interconnectedness leads to systemic risk).

166 See William K. Sjostrom, Jr., The AIG Bailout, 66 Wash. \& LeE L. Rev. 943, 979 (2009) (noting that “[b]ecause of AIG's size and interconnectedness . . it was feared that AIG's failure would lead to the collapse of the entire financial system").

167 See Schwarcz, supra note 163, at 200-01 (contrasting uncorrelated individual risk with correlated systemic risk that affects every market participant); Coffee, supra note 124, at 816-17 (noting that financial institutions were exposed to increasingly correlated risk in the years prior to 2008). 
ment policies? The following three choices are among the most obvious options.

\section{a. Higher Equity Capital Requirements}

Raising equity capital requirements makes sense, but banks will quietly resist this option because it reduces leverage and thus bank profitability. A variant on this general technique is to employ contingent capital-a debt security that automatically converts by its terms into an equity security when the institution encounters a defined level of economic stress. ${ }^{168}$ This conversion dilutes equity shareholders and thereby forces them to bear some of the costs of their preference for high leverage.

\section{b. A Private, Industry-Funded Insurance System}

Such an insurance system is essentially what the Federal Deposit Insurance Corporation (FDIC) manages, and it has long been the preferred policy of the International Monetary Fund (IMF). ${ }^{169}$ Essentially, it replaces a public bailout with a private-industry bailout, and forces the banking industry to internalize the costs of higher leverage. Put differently, this approach taxes the externality by imposing a charge on the industry to prefund such an insurance fund; thus, as with contingent capital, this approach also offsets the externality that arises when TBTF banks borrow funds too cheaply because of an expected governmental guarantee. ${ }^{170}$

\section{c. Reducing Risk Through Prophylactic Rules}

A third approach is to reduce the risk level of TBTF banks by denying them authority to engage in certain higher risk activities. As discussed later, the "Volcker Rule," which the Dodd-Frank Act partially adopted, intends such a result by prohibiting large banks from engaging in proprietary trading or running hedge funds. Similarly, the now-repealed Glass-Steagall Act separated investment banking

168 This conversion could be piecemeal and progressive, as the stock price fell to various lower levels, or it could occur when certain accounting-based tests are triggered. The conversion could be to a common stock or to a preferred stock (possibly with special voting rights). Either way, the primary goal is to avert bankruptcy and financial contagion. For a fuller review of the potential designs for contingent capital, see Coffee, supra note 124, at 828-33.

169 See Linda Yueh, IMF Gets Tough on Banks with 'FAT' Levy, Guardian (Apr. 21, 2010, 6:58 PM), http://www.guardian.co.uk/commentisfree/2010/apr/21/imf-levy-bank-fat-tax (noting that the IMF proposed a "financial stability contribution" toward a self-insurance fund equivalent to 4-5\% of each country's GDP (internal quotations omitted)).

170 For the case for such a private, prefunded fund, see Jeffrey N. Gordon \& Christopher Muller, Confronting Financial Crisis: Dodd-Frank's Dangers and the Case for a Systemic Emergency Insurance Fund, 28 YALE J. ON REG. 151, 157-204 (2011). 
from commercial banking, partly in order to protect the latter institutions. ${ }^{171}$

The Dodd-Frank Act mandates only the last of these steps, through a provision popularly known as the Volcker Rule. ${ }^{172}$ It will be discussed shortly, but it is the primary exception to the generally accurate generalization that the Dodd-Frank Act did not mandate stricter standards on TBTF banks, but only authorized regulators to do so. For example, although the Dodd-Frank Act authorizes the Federal Reserve to impose higher and more restrictive standards with regard to bank capital and leverage, it did not direct any specific action and instead leaves these issues to the discretion of the Federal Reserve Board (FRB) and a new body called the Financial Stability Oversight Council (FSOC). ${ }^{173}$ At earlier stages in the Dodd-Frank legislation, both the House and Senate versions of the Act contained important provisions mandating a private industry insurance fund (modeled after the FDIC); Congress ultimately deleted these provisions at the conference stage. ${ }^{174}$ Why? Populist anger at the costly bailout of the banks compounded by resentment over continued high executive compensation in the financial industry made any proposal that arguably contemplated another bailout politically unacceptable. ${ }^{175}$ In addition, some feared that the existence of such a fund would perpetuate a moral hazard problem as creditors would feel protected and continue to lend at a discount. ${ }^{176}$

Instead, Congress focused the Dodd-Frank Act on prohibiting future public bailouts by the Federal Reserve or the FDIC. To this end, regulators were stripped of their former authority to advance funds to major financial institutions facing a liquidity crisis. ${ }^{177}$ Yet, it is still not

171 See id. at 190.

172 See Dodd-Frank Wall Street Reform and Consumer Protection Act (Dodd-Frank Act), Pub. L. No. 111-203, $\$ 619,124$ Stat. 1376, 1620-31 (2010) (codified at 12 U.S.C. $\S 1851$ (Supp. IV 2010)). For a fuller review of the rule, see David H. Carpenter \& $\mathbf{M}$. Maureen Murphy, The "Volcker Rule": Proposals to Limit "Speculative" Proprietary Trading by Banks, Conc. Research Serv., 10-20 (June 22, 2010), http://www.fas.org/sgp/crs/misc/ R41298.pdf.

173 See Dodd-Frank Act $\$ 111$ (codified at 12 U.S.C. $\$ 5321$ ) (establishing the Financial Stability Oversight Council).

174 See Gordon \& Muller, supra note 170, at 193.

175 See id. (noting that this proposal was "[a]ttacked as fostering bailouts" (internal quotations omitted)).

176 See id. at 207; Admati, supra note 123, at iii (noting that such a fund "could create significant distortions, particularly excessive risk taking”).

177 Section 1101(a) (6) of the Dodd-Frank Act restricts the Federal Reserve Board's (FRB) former authority under section 13(3) of the Federal Reserve Act to make emergency loans to a failing institution. Dodd-Frank Act $\$ 1101$ (a) (6) (codified at 12 U.S.C. $\S 343$ ). Under section 1101 (a)(6), the FRB can no longer lend to a single firm, but can make emergency loans "for the purpose of providing liquidity to the financial system, and not to aid a failing financial company." See id. Such lending must be incident to a "program or facility with broad-based eligibility." See id. Further, section 1101 (a)(6) provides that such 
clear that the market really believes that any future administration could truly tolerate a major bank failure and may suspect that some means would be found to evade statutory obstacles in a major crisis. A future Administration might also be unwilling to liquidate a failing financial institution if its liquidation would be read politically as a failure of oversight on its part. Even among experienced practitioners, uncertainty surrounds what will actually happen the next time a major liquidity crisis erupts and a significant financial institution nears insolvency. ${ }^{178}$ Possibly, the FDIC could liquidate the bank, but still spare its creditors by forming a "bridge company" whose debts would be assumed or guaranteed by it. ${ }^{179}$ As a result, the market may still consider the creditors of large banks to be protected from failure, and hence the TBTF subsidy may continue, even if to a reduced degree.

Rightly or wrongly, the Dodd-Frank Act seeks to cut off the possibility of central-bank emergency funding for a distressed bank in order to end the idea that a bank can be "too big to fail." This reverses a policy followed by most central banks since at least the late 18th century, when Walter Bagehot defined the role of the central banker as serving as the lender of last resort. ${ }^{180}$ Although a policy of ending emergency funding is at least a relevant response to the problem of

loans must be fully and adequately collateralized in a manner that "is sufficient to protect taxpayers from losses." See id. Neither Lehman nor AIG could satisfy this standard. Finally, section 1101 (a) (6) specifically denies the FRB the power to make loans to a "single and specific company" under its emergency lending authority or to make loans "for the purpose of assisting a single and specific company avoid bankruptcy, resolution under title II of the Dodd-Frank" Act. See id. In substance, this language means that the Federal Reserve's emergency lending authority cannot extend to a targeted bailout loan to a future Lehman, AIG, or Bear Stearns.

In the case of the FDIC, which is permitted to lend to a "covered financial company" in receivership under section 204(d) of the Dodd-Frank Act, section 212(a) ("No Other Funding") bars the provision of funds by the FDIC to such companies outside of a Title II receivership. See id. $\$ \$ 204$ (d), 212(a) (codified at 12 U.S.C. $\$ \S 5384,5392$ ). Although the FDIC can guarantee the obligations of a firm that is being liquidated (and there is no ceiling on its authority in this regard), it can do nothing for an individual firm that remains solvent. See id. $\$ 212$ (a). Possibly, the FDIC will continue to arrange mergers or purchases and assumptions.

178 Several experienced banking and securities law practitioners expressed this view to this author at conferences and symposia. Many believe the Federal Reserve both could and would find ways to skirt statutory obstacles in a major crisis, but these critics also recognize that political considerations might deter the Federal Reserve in a lesser crisis. Furthermore, few institutions, aside from Congress, have standing to challenge unauthorized Federal Reserve lending. Still, because the Federal Reserve has received intense criticism and "second guessing" from Congress since 2008, it has to fear that any defiance by it of Congress's intent could lead to loss of its autonomy. The bottom line is that it is hard to predict whether and how far the Federal Reserve might go to bend the law.

179 Section 204(d) of the Dodd-Frank Act gives the FDIC this authority once it chooses to liquidate the financial institution. See supra note 177.

180 See Walter Bagehot, Lombard Street: A Description of the Money Market 196-98 (1873) (outlining the duties of a central bank during a banking panic). 
the TBTF subsidy, it is a Draconian policy that represents a huge gamble.

Put simply, the core problem is that banks are inherently fragile. Banks and similar financial institutions are subject to a fundamental mismatch between the short-term character of their liabilities and the longer-term character of their assets. ${ }^{181}$ Depositors expect and receive high liquidity, while borrowers expect to repay their loans over a longer, multiyear period. In good times, banks profit from this maturity transformation, realizing the spread between the lower rates paid to depositors and the higher rate charged to borrowers. But, in bad times, banks have been classically subject to "runs" when depositor confidence is shaken. ${ }^{182}$

Although investment banks differ from commercial banks in that they do not have depositors, investment banks are equally subject to the same mismatch of short-term liabilities and long-term assets because typically they finance operations with short-term, overnight borrowings in the "repo" market. ${ }^{183}$ Thus, when the market suspects that a financial institution is subject to a risk of insolvency, short-term creditors may stage their own bank run by refusing to renew short-term credit lines or vastly increasing the interest rate. This functional equivalent to a depositor run happened not only at Bear Stearns and Lehman, but also across the banking system in 2008. ${ }^{184}$ Yale Economics Professor Gary Gorton argues that the 2008 panic differed from most panics in the nineteenth and early twentieth centuries in that it was not a "retail" panic, but a "wholesale" panic because the market learned suddenly that the banking system as a whole was insolvent. ${ }^{185}$

This point about the wholesale character of the crisis explains why reforms such as private, industry-funded bailout funds are un-

\footnotetext{
181 For an overview, see Richard A. Posner, A Failure of Capitalism: The Crisis of '08 ANd the Descent Into Depression 128-30 (2009).

182 For standard accounts of this mismatch, see generally Charles W. Calomiris \& Joseph R. Mason, Fundamentals, Panics, and Bank Distress During the Depression, 93 AM. EcoN. Rev. 1615 (2003); Douglas W. Diamond \& Philip H. Dybvig, Bank Runs, Deposit Insurance, and Liquidity, 91 J. Pol. Econ. 401 (1983). For a concise summary of this literature as it applies to the 2008 crisis, see Gordon \& Muller, supra note 170, at 158-66.

183 The term "repo" refers to security repurchase agreements, which usually involve highly liquid, investment-grade securities that the borrower sells to the creditor at a slight discount but agrees to repurchase at the higher market price on a very short-term basis. If the borrower fails to repurchase, it suffers the loss of this discount. For discussion of the repo market and its destabilizing impact on the contemporary banking system, see generally Gary Gorton \& Andrew Metrick, Regulating the Shadow Banking System, Brookincs PAPERS ON ECON. Activitr, Fall 2010, at 261.

184 See Gary Gorton, Slapped in the Face by the Invisible Hand: Banking and the Panic of 2007 4-5 (May 9, 2009) (unpublished Federal Reserve Bank of Atlanta 2009's Financial Markets Conference paper), available at http://papers.ssrn.com/sol3/papers.cfm?abstract id $=1401882$.

185 See id. at $37-38$.
} 
likely to independently prove adequate. Insurance can work to avert a crisis when a small percentage of the industry may fail, but not when a plurality may fail concurrently because of risk correlation. A private insurance fund might be sufficient to bail out a Lehman, but not the aggregate of Lehman, Citigroup, and Goldman Sachs. To the extent that a systemic risk crisis is provoked by risk correlation, multiple contemporaneous failures become more likely that it could dwarf such a fund. In 2009, the crisis threatened much of the financial industry and the banking system effectively froze. ${ }^{186}$

The Dodd-Frank Act withdraws traditional emergency lending authority from the FRB and the FDIC for solvent banks facing only liquidity crises. Its failure to adopt any FDIC-like, prefunded private insurance bailout fund may prove in time to have been right or wrong, but it was certainly not the product of "policy entrepreneurs" and activist-investors that Professors Romano and Bainbridge accuse of "highjacking" the legislation. Moreover, these actions withdrawing authority from financial regulators underscore the importance of the two affirmative steps that the Dodd-Frank Act did take: (1) it sought to reduce systemic risk at large financial institutions by adopting the Volcker Rule, and (2) it authorized the FRB to adopt higher capital, liquidity, and related prudential standards.

At the end of the day, the Dodd-Frank Act tied the hands of financial regulators in some respects, denying them their traditional authority to structure bailouts, but delegated them great discretion in other respects, while mandating relatively little. This strategy's effectiveness depends on whether the current political environment allows for effective implementation; today, there are substantial reasons to doubt that it does.

\section{The Over-the-Counter (OTC) Derivatives Market}

The 2008 financial crisis crested when, in rapid succession, Lehman failed and AIG was bailed out. Lehman is, arguably, a paradigm TBTF bank; AIG's story, however, is more complex. AIG's failure had the potential to sink far more counterparties than Lehman's failure ever conceivably could.

In response to the AIG episode, the Dodd-Frank Act sought to bring transparency to the OTC market by mandating the use of clearinghouses, exchange trading of OTC derivatives, and trade reporting. This effort was entirely rational and may yet be successful, but its suc-

\footnotetext{
186 See Victoria Ivashina \& David Scharfstein, Bank Lending During the Financial Crisis of 2008, 7-8 (Jul. 2009) (unpublished working paper), available at http://papers.ssrn.com/ sol3/papers.cfm?abstract_id=1297337 (finding that in the fourth quarter of 2008, new loans to large borrowers fell by $47 \%$ in comparison to the prior quarter, as banks cut back lending).
} 
cess is very much in doubt. Title VII of the Dodd-Frank Act establishes for the first time an integrated legal regime for the regulation of the derivatives market, assigning security-based swaps to the SEC and other swaps to the Commodities Futures Trading Commission (CFTC). ${ }^{187}$ Although this division perpetuates the United States' long-standing preference for a multi-peaked regulatory structure, the two agencies seem to be operating in unison-at least for the time being. Both agencies seek to increase the standardization of swap agreements in order to facilitate their trading through a central clearinghouse. ${ }^{188}$ The key goal is to eliminate counterparty risk for dealers and investors by replacing the bilateral trading of OTC derivatives with trading through a centralized clearinghouse. ${ }^{189}$

Inevitably, such a restructuring does not eliminate risk, but only shifts it. The new central clearinghouses will bear the counterparty risk, and the failure of any major clearinghouse could be an event that triggers a major systemic-risk crisis. Systemic risk is once again concentrated with the creation of another TBTF institution.

Because private mechanisms for dealing with counterparty risk failed in 2008-and indeed many financial institutions did not require major dealers, including AIG, to post collateral to secure their trades until the advent of the crisis-the case for use of clearinghouses is strong, but not without problems. ${ }^{190}$ Critics of the idea believe that clearinghouses are inherently exposed to failure. They argue that clearinghouses are bureaucratic institutions less able or willing to assess risk positions in credit default swaps because they are less motivated by profit opportunities than are individual dealers. ${ }^{191}$ Others argue that a meaningful reduction of counterparty risk in swap trading through multilateral netting of investment positions in a clearinghouse requires that the vast majority of the volume in swaps traded must clear through that clearinghouse. ${ }^{192}$ To work, the clearinghouse must gain a near monopoly.

187 For overviews of regulation in these markets, see generally Jeremy C. Kress, Credit Default Swaps, Clearinghouses, and Systemic Risk: Why Centralized Counterparties Must Have Access to Central Bank Liquidity, 48 HARv. J. ON LegIs. 49 (2011); Jonathan Urban, Developments in Banking and Financial Law: 2009-2010: The Shadow Financial System, Regulation of Over-theCounter Derivatives: The Ultimate Lesson of Regulatory Reform, 29 REv. Banking \& Fin. L. 1, 49-57 (2010); Further Definition of "Swap Dealer," "Security-Based Swap Dealer," "Major Swap Participant," "Major Security-Based Swap Participant" and "Eligible Contract Participant," Exchange Act Release No. 63,452, 75 Fed. Reg. 80174 (Dec. 21, 2010) (proposing rules to be codified at 17 C.F.R. 240).

188 See Kress, supra note 187, at 69-71.

189 See id. at 65-69.

190 See id. at 72-76.

191 See Craig Pirrong, The Clearinghouse Cure, Reg., Winter 2008-2009, at 44, 47-48.

192 See Darrell Duffie \& Haoxiang Zhu, Does a Central Clearing Counterparty Reduce Counterparty Risk?, 1 Rev. Asset Pricing Stud. 74, 76-77 (2011). 
But here politics intervened. The Dodd-Frank Act contains an important end-user exemption, which exempts from its swaps mandatory clearing requirement any counterparty who (1) is not a "financial entity," (2) uses the swap to hedge or mitigate commercial risk, and (3) notifies the appropriate regulatory agency (SEC or CFTC) as to how it generally meets its financial obligations associated with entering into such noncleared swaps. ${ }^{193}$ Politically, this was necessary to exempt major swap users who might have otherwise blocked the legislation, like major airlines seeking to hedge the future cost of aviation fuel. Such end users did not wish to be subjected to the minimum capital and margin requirements that the Dodd-Frank Act imposed on swap dealers. ${ }^{194}$ The consequence is that much of the volume in swaps will not be cleared and will escape margin requirements.

The SEC and the CFTC proposed a joint rule to distinguish the commercial end user from more speculative financial investors in swaps. ${ }^{195}$ Under it, much of swap trading will escape the collateral and capital rules intended to mitigate systemic risk. ${ }^{196}$ One cannot fault the two agencies for obeying Congress, but politics has produced a strange hybrid that could either reduce or exacerbate systemic risk. A second difficulty compounds this vulnerability: nonstandardized swap contracts cannot be easily cleared. ${ }^{197}$ Worse yet, forcing complex derivatives into clearinghouses increases the operational risk for the clearinghouse because it requires clearinghouses to clear products that they cannot easily price (and thereby set appropriate margins). ${ }^{198}$ To the extent that clearinghouse members have a better, more accurate understanding of these risks, they will possess asymmetric information and may trade to their advantage and the clearinghouse's disadvantage. ${ }^{199}$ Although swap dealers would have to share the costs of a clearinghouse failure, each has an incentive to trade against the clearinghouse in a way that increases in the aggregate the risk of systemic failure. ${ }^{200}$

\footnotetext{
193 See 7 U.S.C. § 2(h) (2010).

194 See 15 U.S.C. $\$ 8323$ (a) (2010).

195 See End-User Exception to Mandatory Clearing of Security-Based Swaps, Exchange Act Release No. 63,556, 75 Fed. Reg. 79992 (Dec. 21, 2010).

196 See id.

197 See Pirrong, supra note 191, at 49 (noting that "the more complex the product... the greater the cost of sharing a risk through a [clearinghouse] relative to the cost of ... the over-the-counter market" ${ }^{n}$ ).

198 See Int'l Monetary Fund, Global Financial Stability Report: Meeting New Challenges to Stability and Building a Safer System 91 (2010), available at http:// www.imf.org/external/pubs/ft/gfsr/2010/01/pdf/text.pdf.

199 See Pirrong, supra note 191, at 47-48.

200 See id.
} 
IV

\section{The Implementation of the Dodd-Frank Act}

The foregoing section argued that the Dodd-Frank Act is a skeletal structure with few affirmative commands and is heavily dependent on administrative implementation. As noted earlier, the financial industry's best opportunity to nullify costly regulation is often at the administrative implementation stage because: (1) the administrative process is less visible and politically accountable; (2) some agencies, most notably the FRB, may be too closely aligned with the financial entities they are to regulate; or (3) the financial industry can both win concessions through negotiations and then challenge in court those regulations not otherwise watered down. In addition, the Regulatory Sine Curve discussed earlier suggests that regulatory ardor wanes once the sense of emergency is lost.

Against that backdrop, this Article next surveys the progress of the Dodd-Frank Act's implementation in three critical areas: (1) the attempt to curb excessive executive compensation, (2) the effort to end the TBTF problem by restricting risky activities that may cause bank failure, and (3) the effort to move OTC trading out of the shadows and into the sunlight of greater transparency. At this stage, it is still premature to evaluate implementation with respect to the last two objectives, but a fuller assessment of the effort to curb executive compensation is possible.

\section{A. Curbing Executive Compensation: The Road Not Taken}

A major goal of the Dodd-Frank Act was to reduce the danger of moral hazard by better relating executive compensation to long-term performance. The Dodd-Frank Act approached this goal by two distinct means, both of which are now largely frustrated. This subpart examines each separately.

\section{Proxy Access and Corporate Governance}

As already noted, the Dodd-Frank Act authorized the SEC to use the standard inventory of corporate governance reform-proxy access, "say-on-pay," and a restriction on broker voting - to make corporate managers more accountable to shareholders. ${ }^{201}$ As discussed above, this may have been an ill-advised tactic, at least in the context of large financial institutions where excessive leverage needed to be discouraged. But vastly overshadowing the significance of the SEC's efforts are the consequences of the industry's response. In particular, the implications of the D.C. Circuit's decision to invalidate the SEC's 
proxy access rule in Business Roundtable v. SEC ${ }^{202}$ cast a substantial cloud over the SEC's continuing ability to adopt other rules in implementing the Dodd-Frank Act, even those not related to corporate governance.

In adopting its proxy access rule (Rule 14a-11), the Commission relied on Section 971 of the Dodd-Frank Act, which authorized, but did not mandate, the Commission to adopt a rule allowing shareholders an alternative means by which to nominate and elect directors. ${ }^{203}$ Because the Commission was given discretion, the rule was subject to Section 3(f) of the Securities Exchange Act of 1934, which requires the SEC, when determining if a rule is in the public interest, to "also consider, in addition to the protection of investors, whether the action will promote efficiency, competition, and capital formation."204 On its face, this language is relatively soft, mandating that the Commission only consider these impacts, not that the SEC determine that the interests of investor protection outweigh those of efficiency, competition, and capital formation. Nonetheless, the D.C. Circuit has invalidated SEC rules several times under this provision, finding that the Commission has a "statutory obligation to determine as best it can the economic implications of the rule."205

In fact, the SEC did consider several economic studies on the likely impact of encouraging the election of dissident candidates and expressly noted the limitations of these studies. In their lawsuit, the Business Roundtable and the Chamber of Commerce asserted both that (1) "the Commission failed to appreciate the intensity with which issuers would oppose nominees and arbitrarily dismissed the probability that directors would conclude their fiduciary duties required them to support their own nominees,"206 and (2) the Commission arbitrarily failed "to estimate the costs of solicitation and campaigning that companies would incur to oppose candidates nominated by shareholders." ${ }^{207}$ Thus, the D.C. Circuit invalidated a rule intended to tilt the advantage in corporate board elections in favor of

202647 F.3d 1144 (D.C. Cir. 2011).

203 The Commission proposed the proxy-access rule in December 2009. See Facilitating Shareholder Director Nominations, Securities Act Release No. 9086, Exchange Act Release No. 61,161, Investment Company Act Release No. 29,069, 74 Fed. Reg. 67,144 (proposed Dec. 18, 2009). The Commission adopted the proxy-access rule in September 2011. See Facilitating Shareholder Director Nominations, Securities Act Release No. 9259, Exchange Act Release No. 65,343, Investment Company Act Release No. 29,788, 76 Fed. Reg. 58100 (Sept. 20, 2011) (to be codified at 17 C.F.R. pts. 200, 232, 240, and 249).

204 See Securities Exchange Act of $1934 \S 3$ (f) (codified at 15 U.S.C. $\S 78 c(f)(2006)$ ). Similar language also appears in the Investment Company Act. See, e.g., 15 U.S.C. $\S 80 \mathrm{a}-2(\mathrm{c})$.

205 See Chamber of Commerce v. SEC, 412 F.3d 133, 143 (D.C. Cir. 2005). See also Am. Equity Inv. Life Ins. Co. v. SEC, 613 F.3d 166, 167-68, 178 (D.C. Cir. 2010).

206 See Bus. Roundtable, 647 F.3d at 1149.

207 See id. at 1150. 
dissident shareholders precisely because the Commission did not, or could not, estimate the costs of the hostile corporate reaction to such efforts. By analogy, this is equivalent to invalidating an Environmental Protection Agency (EPA) rule prohibiting toxic waste dumping into rivers and waterways because the EPA did not, or could not, adequately estimate the costs to companies of alternative means of disposal.

Still, the most relevant issue for this Article is the decision's impact on future SEC attempts to adopt rules under the Dodd-Frank Act. The critics of SEC attempts to "federalize" corporate law by mandating corporate governance practices will celebrate the Business Roundtable decision because it seems to require the Commission to consider the empirical studies that they feel Congress disregarded in the enactment of SOX. Presumably, the D.C. Circuit would not attempt to hold Congress to this same standard, but to the extent that Congress enacts legislation giving the SEC any discretion as to the means to be used, the D.C. Circuit may closely review the SEC's exercise of that discretion under the Section 3(f) standard.

This problem is not limited to SEC rules addressing corporate governance. Eventually, when the SEC adopts rules implementing the Volcker Rule in Section 619 of the Dodd-Frank Act or mandating the use of clearinghouses or exchanges for security-based swaps trading, some interest group or individual financial institutions will feel aggrieved and sue. One cannot predict the outcome of such litigation today, but it is sufficiently threatening that an overworked and underfunded SEC may feel intimidated and compromise its rules, watering them down, to avoid the risk of another humiliating decision from the D.C. Circuit. Although Congress could legislate its own standards without delegating the matter to administrative agencies, that would imply abandoning the contemporary administrative state and reliance on administrative expertise. Not since the New Deal has the prospect of judicial challenge to legislative supremacy loomed as large on the horizon. To be sure, Congress could curb the D.C. Circuit's activism, but in the current polarized political environment such an effort seems unlikely.

\section{Section 956}

Congress did not rely exclusively, or even primarily, on corporate governance reforms to curb excessive executive compensation. Section 956 of the Dodd-Frank Act broadly authorized financial regulators to limit excessive compensation, but financial regulators have been equivocal at best, or cowardly at worst, in exercising the powers 
that Section 956 conferred on them. ${ }^{208}$ Somewhat vaguely, Section 956 instructed a "covered financial institution" to disclose to its respective regulator "the structures of all incentive-based compensation" paid to officers, directors and employees, to enable the regulator to prohibit excessive incentive-based compensation "that could lead to material financial loss to the covered financial institution."209

The legal issue here was how broadly to construe this disclosure obligation. Although Section 956 made clear that it did not require the disclosure of the individual executive's compensation, ${ }^{210}$ regulators could have insisted on quantitative data about the aggregate incentive compensation paid by the firm and its distribution among employees and executives. What could such disclosure reveal that might be of material interest to investors? The following chart, taken from a study conducted by then New York Attorney General Andrew Cuomo of incentive compensation received in 2008 by employees of the original TBTF financial institutions that received funds under the Troubled Asset Relief Program (TARP) shows the disclosures that Section 956 could have, but did not, mandate. ${ }^{211}$

Selected TARP Recipients 2008 Bonus Compensation

\begin{tabular}{|c|c|c|c|c|}
\hline Institution & $\begin{array}{c}\text { Earnings / } \\
\text { (Losses) }\end{array}$ & Bonus Pool & $\begin{array}{c}\text { No. of } \\
\text { Employees } \\
\text { Receiving } \\
\text { Bonus } \geq \$ 3 \\
\text { million }\end{array}$ & $\begin{array}{c}\text { No. of } \\
\text { Employees } \\
\text { Receiving } \\
\text { Bonus } \geq \$ 1 \\
\text { million }\end{array}$ \\
\hline Bank of America & $\$ 4$ billion & $\$ 3.3$ billion & 28 & 172 \\
\hline Citigroup, Inc. & $\$(27.7$ billion $)$ & $\$ 5.33$ billion & 124 & 738 \\
\hline Goldman Sachs Group & $\$ 2.322$ billion & $\$ 4.823$ billion & 212 & 953 \\
\hline J.P. Morgan Chase \& Co. & $\$ 5.6$ billion & $\$ 8.693$ billion & $>200$ & 1,626 \\
\hline Merrill Lynch & $\$(27.6$ billion $)$ & $\$ 3.6$ billion & 149 & 696 \\
\hline Morgan Stanley & $\$ 1.707$ billion & $\$ 4.475$ billion & 101 & 428 \\
\hline
\end{tabular}

As this chart demonstrates, even when financial institutions, like Citigroup and Merrill Lynch, lost billions, they still paid out bonuses in the billions to hundreds of employees. ${ }^{212}$ Even in the case of firms

208 See Dodd-Frank Wall Street Reform and Consumer Protection Act (Dodd-Frank Act), Pub. L. No. 111-203, §956, 124 Stat. 1376, 1905 (2010) (codified at 12 U.S.C. § 5641 (Supp. IV 2010)).

209 See id. Dodd-Frank does not require the disclosure of the actual compensation of any particular individual, but only the structure of incentive compensation. The term "covered financial institution" is broadly defined to include depositary institutions, broker-dealers, and other financial institutions having more than $\$ 1$ billion in assets. See id.

210 See id. ("Nothing in this section shall be construed as requiring the reporting of the actual compensation of particular individuals.").

211 See Andrew M. Cuomo, No Rhyme or Reason: The 'Heads I Win, Talls You Lose' Bank Bonus Culture 5 (2009), available at http://www.ag.ny.gov/sites/default/files/ press-releases/archived/Bonus\%20Report\%20Final\%207.30.09.pdf.

212 See id. 
like Goldman, J.P. Morgan and Morgan Stanley, the bonus pool was often a multiple of earnings. ${ }^{213}$ Moreover, practices at these firms varied significantly, making firm-specific disclosure more important. Reading the Cuomo data more closely, one finds that the following number of employees received over $\$ 10$ million in bonus compensation in 2008 at these firms: Merrill Lynch (14), Morgan Stanley (10), J.P. Morgan Chase \& Co. (10), Goldman Sachs (6), Bank of America (4), and Citigroup (3).214 In sum, the Cuomo data underscores three conclusions: (1) the bonus culture persisted even in bad times, (2) bonus payments to executives often was a multiple of distributions to shareholders, and (3) some individuals received extraordinary incentive compensation that could logically cause a moral hazard problem.

Revealing as this information may be, disclosure pursuant to new Section 956 will not yield anything remotely equivalent. This is because the major financial regulators have read Section 956 narrowly. The first interpretive problem posed by Section 956's broad language involved identifying those persons whose behavior could inflict "material financial loss" on their institutions. Section 956 subjects only incentive compensation to regulation. ${ }^{215}$ Obviously, the bank's janitor cannot ordinarily inflict a material financial loss, but the history of broker-dealer firms suggests that traders often can-as happened in recent memory at both Barings Bank and Societe Generale. ${ }^{216}$

In April 2011, the principal financial regulators responded in unison to Section 956's interpretive challenge and each adopted a joint set of rules. ${ }^{217}$ In the case of any financial institution with total consolidated assets of $\$ 1$ billion or more, these rules require an annual report that

describes the structure of the covered financial institution's incentive-based compensation arrangements ... that is sufficient to allow an assessment of whether the structure or features of those arrangements provide or are likely to provide covered persons with excessive compensation, fees, or benefits to covered persons or could lead to material financial loss to the covered financial institution. ${ }^{218}$

\footnotetext{
213 See id.

214 See id. at 6-11.

215 See Dodd-Frank Act $\$ 956$ (a) (1).

216 See, e.g., Nick Thompson, The World's Biggest Rogue Traders in Recent History, CNN (Sept. 15, 2011), http://edition.cnn.com/2011/BUSINESS/09/15/unauthorized.trades/ index.html.

217 See Incentive-Based Compensation Arrangements, Exchange Act Release No. 64,140, 76 Fed. Reg. 21,170, (Apr. 14, 2011). The Treasury, FRB, FDIC, and other agencies proposed similar releases contemporaneously. See id.

218 See Regulation S-P, Regulation S-AM, and Incentive-Based Compensation Arrangements, 76 Fed. Reg. 21,215 (proposed Apr. 14, 2011) (to be codified at 17 C.F.R. 248.204(a)).
} 
This is rather general and abstract language, and no specific data was required. For example, regulators might have followed Andrew Cuomo's lead and required disclosure of the number of employees at a firm who received bonuses of over $\$ 1$ million in the prior year, even if none were identified by name. ${ }^{219}$ Instead, the new rules require only a generalized narrative description, not a disclosure of quantitative data. ${ }^{220}$ This generalized narrative description is likely to produce long-winded boilerplate from securities lawyers adept at covering the waterfront in opaque prose.

In the case of TBTF financial institutions with over $\$ 50$ billion in total consolidated assets, however, more was required by these regulations. Such institutions must provide a description of "incentive-based compensation policies and procedures" for two categories of persons: (1) executive officers, and (2) such "[o]ther covered persons who the board of directors, or a committee thereof, of the covered financial institution has identified ... individually have the ability to expose the covered financial institution to possible losses that are substantial in relation to the covered financial institution's size, capital, or overall risk tolerance."221 Again, this stops well short of revealing the full depth of the firm bonus culture because many-potentially hundreds of employees-could receive incentive compensation in the million dollar range and yet be exempted from disclosure because the board did not believe they could cause a "substantial loss" to the firm.

In short, only in the case of TBTF institutions do the rules require any specific disclosure or serious assessment of who could actually cause a substantial loss to the financial institution, but even in these cases, the regulations still delegate to each covered financial institution the determination of who, beyond its executive officers, could expose it to such a substantial loss. This delegation is significant because only the identified covered persons and executive officers become subject to additional substantive requirements. In the case of the executive officers of these TBTF institutions, the proposed rules require deferral of at least $50 \%$ of the annual incentive-based compensation awarded for a period of not less than three years. ${ }^{222}$ That deferral may or may not be adequate, but the real surprise in these regulations is that, in the case of those persons specifically identified by the TBTF institution's board as being capable of exposing the institution to substantial loss, no deferral was required. Instead, all that Section 956 mandated was that the board or committee approve the

219 See Cuomo, supra note 211 , at 5.

220 See supra note 218 and accompanying text.

221 See 76 Fed. Reg. at 21,215.

222 See id. at 21,216 ("Prohibitions") (requiring a 50\% deferral for "executive officers" (as defined) of "covered financial institutions" with assets in excess of $\$ 50$ billion). 
incentive-based compensation arrangements for such persons and further determine "that the arrangement ... effectively balances the financial rewards to the covered person and the range and time horizon of risks associated with the covered person's activities, employing appropriate methods for ensuring risk sensitivity such as deferral of payments." ${ }^{223}$ In short, the only requirement for those persons the firm identifies as capable of causing it substantial losses is that the board or committee thinks seriously about deferral or some other means of ensuring "risk sensitivity."

Thus, the proposed rules fall breathtakingly short of adequacy on two major grounds: (1) they wholly delegate to the firm the decision of who could cause it substantial loss, and (2) even with respect to the persons so identified, the rules require only process and no minimum deferral. In the implementation of financial regulations, transparency appears to be the first casualty.

Why have financial regulators, in common, pulled their punches by (1) requiring little specific data; (2) allowing the firms to alone decide who, besides executive officers, can cause them significant loss; and (3) not requiring some deferral of bonuses by even the persons so identified? The most plausible answer is that regulators knew that a more effective rule might provoke significant employee defections, as star traders might move from investment banks to less regulated trading firms. Realistically, the nonexecutive officer most likely to cause a substantial loss to a covered financial institution is a trader authorized to trade on a large position basis. Such traders have in recent memory caused staggering losses to some financial institutions-for example, Nicholas Leeson at Barings Bank and Jerome Kerviel at Societe Generale. ${ }^{224}$

Although it is likely that most covered firms will report some employees who can cause it substantial losses, the number so reported will likely be far below the number that covered firms would disclose if more objective criteria were used. Underreporting this number of such persons has several attractions: (1) it makes the firm appear safer in general, (2) it spares the board or committee the obligation to engage in additional specific assessments of whether adequate risk sensitivity has been structured into each such person's incentive compensation, and (3) it ensures that the persons who firms would otherwise identify as capable of causing "substantial loss" will not be restricted in their compensation by the appropriate regulatory agency. That is, if more were identified, the relevant regulator might still de-

\footnotetext{
223 See id.

224 See supra note 216 and accompanying text. Nicholas Leeson's unauthorized trades caused the 1995 Barings Bank failure, and Jerome Kerviel racked up losses in excess of 5 billion pounds at Societe Generale in 2008. See id.
} 
termine that there was inadequate risk sensitivity and thus that the compensation was excessive. However, if the star personnel are never so identified, this problem simply does not arise.

To summarize, the problem for the TBTF financial institution was that if highly compensated "stars" were subjected to the same deferral of incentive compensation as executive officers, they might flee covered financial institutions to relocate at hedge funds, smaller banks, or go abroad to escape such controls. Fearing such migration, financial institutions lobbied for a weaker rule (and apparently succeeded). Still, the irony is that few executive officers at financial institution can cause the same injury to a financial institution as can a star trader, as evidenced by the impact of such celebrated rogue traders as Kervais or Leeson. ${ }^{225}$ The choice for financial regulators was between an effective rule and some competitive injury to the TBTF banks. The latter consideration appears to have dominated, and this pattern may recur regularly as the implementation of the Dodd-Frank Act continues.

Executive compensation was the leading topic on which Congress-motivated by taxpayers-showed real anger. Still, once the negotiations moved from Congress to the regulatory agencies, that anger dissipated or at least yielded to the industry's concerns about employee defections and competitive injury. Once again, this demonstrates how quickly and sharply the Regulatory Sine Curve can reverse course.

\section{B. The TBTF Problem}

In the Dodd-Frank Act, Congress sought to address the TBTF bank in several ways: (1) providing for authority to quickly liquidate a failed bank without the interminable process of a bankruptcy proceeding; ${ }^{226}$ (2) reducing the risk level of banks, including by means of the Volcker Rule;227 and (3) authorizing stricter prudential standards, including the use of a contingent capital standard. ${ }^{228}$ As seen with respect to SOX's prohibition of executive loans and, most recently, the Dodd-Frank Act's equivocal executive-compensation rules, administrative interpretation and underenforcement can enervate clear con-

225 To illustrate this irony: an executive officer typically serves as a TBTF institution's general counsel and is thus subject to a $50 \%$ deferral, while a star trader who weekly bets billions of dollars in volatile markets is not subject to any similar deferral. This disparity cannot be easily justified.

226 See Dodd-Frank Wall Street Reform and Consumer Protection Act (Dodd-Frank Act), Pub. L. No. 111-203, §§ 201-17, 124 Stat. 1442-1520 (2010) (codified at 12 U.S.C. \$5381-94 (Supp. IV 2010)) (conferring authority to commence "orderly liquidation").

227 See id. $\$ 619$ (codified at 12 U.S.C. $\$ 1851$ (Supp. IV 2010)).

228 See id. $\$ \S 112(\mathrm{a})(2), 115(\mathrm{~b})$, and $165(\mathrm{~b})$ (codified at 12 U.S.C. $\$ \S 5322,5325$, and 5365). 
gressional statements. 229 Yet, in the case of the Dodd-Frank Act's approach to TBTF institutions, the legislation never articulated clear standards to begin with, and equivocal implementation will likely further weaken these standards.

\section{Resolution Authority}

The fact that financial regulators, acting in virtual unison, can liquidate a TBTF institution before it becomes legally insolvent does not mean that they will actually do so. Such action would imply a black eye for almost any administration, suggesting that the administration was a poor financial watchdog. Regulators might also fear that such action would trigger a financial panic, tempting regulators to kick the can down the road, hoping for the best and seeing little advantage in early intervention. Moreover, as the financial industry grows more concentrated in the wake of the 2008 failures and consequent mergers, the remaining TBTF banks are even larger. As a result, the failure of one of them would be more serious than Lehman's failure. For all these reasons, the TBTF banks have increased incentives to maintain large lobbying cadres in Washington to protect their interests from adverse actions. In any event, regulatory action to liquidate a TBTF institution could never occur quickly because it would require high coordination and unanimity among regulators.

Still, suppose a TBTF bank does fail? At this point, the FDIC may provide financing to a bridge company that acquires most of the failed bank's assets. The FDIC could either decide to bail out the bondholders or end the TBTF subsidy and let the bondholders share in the pain. The highly discretionary character of this choice suggests it too will invite heavy lobbying. In turn, the more that an FDIC fund pays off bondholders, the more that the TBTF subsidy survives. Ultimately, one cannot predict what will happen in any specific case, but the greater the fear of a financial panic, the more financial regulators are likely to want to cause bondholders to be paid in full to avert panic. Little may change, and the TBTF subsidy may persist.

\section{The Volcker Rule}

The Volcker Rule ${ }^{230}$ is a coherent response to the TBTF problem: if banks are too big to fail, they must be regulated so that their risktaking is constrained in order that they not fail. But the Volcker Rule faces political problems. First, there is almost no evidence that proprietary trading was responsible for the failure of any financial institution in the 2008 crisis. In contrast, firms like Lehman failed because of

229 See supra Parts II.B, IV.A.2.

$230 \quad$ See Dodd-Frank Act $\$ 619$. 
their ill-advised principal investments; Lehman made disastrous acquisitions of major real estate lenders and developers including SunCal and Archstone, but those acquisitions, which made it undiversified and overleveraged, fell well outside the definition of proprietary trading in the Dodd-Frank Act. ${ }^{231}$ In this respect, the Volcker Rule is seriously underinclusive because it exempts principal investments from its ban, despite the Lehman experience.

Second, the Volcker Rule contains numerous loopholes and exceptions. ${ }^{232}$ Chief among these are exceptions for hedging and market making by the covered financial institution. ${ }^{233}$ The financial regulators' initial draft of their proposed Volcker Rule surprised many by being tougher and more restrictive than most had expected. ${ }^{234}$ Still, the start of the process is not the end, and opposition to the Rule has rapidly mounted. ${ }^{235}$ Always opportunistic, the financial services industry seized on the European sovereign debt crisis to warn that implementation of the Volcker Rule will curtail the demand for European sovereign debt and aggravate that crisis. ${ }^{236}$ The irony here is that the recent collapse of MF Global, based on its ill-fated bet on European sovereign debt, evidences that proprietary trading in sovereign debt is indeed risky; nonetheless, political pressure is mounting in Europe and elsewhere to insist that TBTF banks in the U.S. continue to support this market. ${ }^{237}$ Once again, the experience with SOX

231 See, e.g., Terry Pristin, Risky Real Estate Deals Helped Doom Lehman, N.Y. TIMEs, Sept. 17, 2008, at C6 (discussing Lehman's multi-billion dollar acquisition of Archstone-Smith). 232 See Dodd-Frank Act $\$ 619$ (d) (1). The Volcker Rule loopholes and exceptions include: (1) underwriting and market-making related activities, (2) risk-mitigating hedging activities, (3) investments driven by customer demand, (4) proprietary trading done outside the United States, and (5) such other activities as regulators determine by rule would promote safety and soundness of the banking system. See id.

233 See id. $\$ 619$ (d)(1)(B), (C).

234 On October 12, 2011, the SEC voted to propose a version of the Volcker Rule that was drafted in common with other financial regulators. See Press Release, U.S. Sec. \& Exch. Comm'n, SEC Jointly Proposes Prohibitions and Restrictions on Proprietary Trading (Oct. 12, 2011), available at http://www.sec.gov/news/press/2011/2011-204.htm. The SEC must adopt a final version of the Rule in 2012, but he SEC has not yet issued a proposed release. 235 See James B. Stewart, Volcker Rule, Once Simple, Now Boggles, N.Y. TrmFs, Oct. 22, 2011, at B1; see also Editorial, So Much for the Volcker Rule, WalL ST. J., Oct. 24, 2011, at A14 (noting that before the SEC adopts a final rule, it must consider some "1,347 queries" to the 298-page proposed rule).

236 See Brooke Masters \& David Oakley, Bankers in Eurozone Warming, Fin. TIMEs, Nov. 22, 2011, at 15. Expressing similar fears, Japan asked that Congress and the SEC relax the Volcker Rule. See Scott Patterson \& Jamila Trindle, Japan Joins the Chorus of 'Volcker Rule' Critics, WaLl ST. J., Jan. 13, 2012, at C3; see also infra note 258 (describing the prediction of two Davis Polk \& Wardwell LLP attorneys that the proposed regulation implementing the Volcker Rule will be withdrawn).

237 See Andrew Ross Sorkin, Volcker Rule Stirs Up Opposition Overseas, N.Y. Times, Jan. 31, 2012, at B1 (noting European governmental pressure to relax the Volcker Rule with regard to trading in sovereign debt, notwithstanding the failure of MF Global, which became insolvent based on such trading). For an overview of the causes of the demise of MF Global, a major dealer in the derivatives market, where some $\$ 1.2$ billion in customer money disap- 
predicts the fate of the Dodd-Frank Act, as the proposed proprietary trading rules appear likely to be watered down.

\section{Contingent Capital}

One of the most original ideas proposed to avert TBTF debacles is a requirement that some portion of the financial institution's debt securities be convertible into an equity security under the original bond contract if the financial institution begins to approach insolvency. ${ }^{238}$ Although the original idea was to convert the debt to equity on the doorsteps of insolvency, much more can be done with this flexible idea. Uniquely, contingent capital provides an ex ante tool. As the stock price of the institution declines, debt could convert at several stages on an incremental basis into an equity security, thereby diluting the equity and punishing the stockholders for their pursuit of higher leverage and risk-taking. Used this way, the tool has a prospective deterrent power. This author has proposed conversion of the debt into a voting preferred stock, whose holders would have incentives naturally aligned with other debt holders and adverse to the common stockholders. ${ }^{239}$ Again, the goal is to create a counterbalancing constituency that would resist shareholder pressure.

Other innovative designs are possible, but the likelihood is high that the Federal Reserve will ignore these possibilities. Instead, the Federal Reserve will likely propose that contingent capital be used only as a form of prepackaged bankruptcy. If insolvency is inevitable, even the financial industry recognizes that it would be quicker and simpler to convert much of the debt into equity than utilize the cumbersome procedures of resolution authority. The banking community would probably also prefer such a modest use of contingent capital because it reduces the uncertainty incident to liquidation and avoids the mandatory ouster of responsible management that "resolution authority" requires.

Still, such a minimal use of contingent capital is myopic. It surrenders the possibility of ex ante measures that could precede and avert insolvency. But if anything can be safely predicted, it is that the Federal Reserve is too closely imbedded within the banking commu-

peared in late 2011, see Ben Protess \& Azam Ahmed, Lax Oversight Is Blamed In Demise of MF Global, N.Y. TIMEs, Feb. 3, 2012, at B6.

238 The author most responsible for the consideration of this bankruptcy-averting technique, in the context of a TBTF institution, is Professor Mark J. Flannery. See Mark J. Flannery, No Pain, No Gain? Effecting Market Discipline via "Reverse Convertible Debentures", in Capital. Adequacy Beyond Basel: Banking, Securities, and Insurance 171, 171-75 (Hal S. Scott ed., 2005); see also Coffee, supra note 124, at 828-33 (reviewing possible designs for the use of contingent capital).

239 See Coffee, supra note 124 , at $805-07,828-34$. 
nity to propose any intrusive remedy that would be invoked well before a banking crisis has begun.

\section{The Legislative Counterattack}

As of early 2012, both the Senate and the House have passed legislation that will severely curtail many of the corporate governance provisions of the Dodd-Frank Act. ${ }^{240}$ Essentially, the pending legislation would create a new category of issuer called an "emerging growth company," which would be exempt from many of the provisions of the proxy rules, including the Dodd-Frank Act's "say-on-pay" and compensation disclosures provisions, as well as Section 404(b) of SOX. ${ }^{241}$ The pending legislation defines an emerging growth company as any issuer that has annual gross revenues of less than $\$ 1$ billion with a public float of less than $\$ 700$ million. ${ }^{242}$ The rationale for this broad exemption is that it would spur job creation by encouraging smaller companies to conduct initial public offerings (IPOs). ${ }^{243}$ Still, neither the Dodd-Frank Act nor Section 404 of SOX could have caused this decline in IPOs, which dates back, at least, to the burst of the Internet

240 The JOBS Act (an acronym for "Jumpstarting Our Business Startups" Act) has been passed by both the House and the Senate and awaits a conference on small issues unrelated to those described in the text. See H.R. 3606, 112th Cong. (2011); S. 1933, 112th Cong. (2011). For a brief description of this legislation, see Michael Rosenberg, United States: IPO "On-Ramp", MondaQ Bus. Briefing (Dec. 27, 2011), http://www.mondaq.com/ unitedstates/x/158710/Capital+Markets/IPO+OnRamp.

241 Senate Bill 1933 and House Bill 3606 have each amended Section 2(a) of the Securities Act of 1933 and Section 3(a) of the Securities Exchange Act of 1934 to define the term "emerging growth company." See, e.g., H.R. 3606, §2(a), (b). Section 14A of the Securities Exchange Act of 1934 ("Shareholder Approval of Executive Compensation"), which mandates a shareholder advisory vote on executive compensation not less frequently than once every three years exempts these issuers so long as currently private companies remained emerging growth companies. See, e.g., S. 1933, §3(a) (1). Disclosure of the median of the annual total compensation of all employees, which was mandated by Section 953(b) (1) of the Dodd-Frank Act, would also be waived for emerging growth companies (as would compliance with Section 404(b) of SOX). See, e.g., H.R. 3606 § 3(a) (3).

242 Senate Bill 1933 and House Bill 3606 require both that the issuer have less than $\$ 1$ billion in gross revenues for its last fiscal year and that the issuer not have common stock held by nonaffiliates with a market value of $\$ 700$ million or more. See, e.g., S. 1933 $\S 2$ (a) (19). The SEC adopted this market value standard, known as the "public float," to define a "well-known seasoned issuer," which is entitled to use automatic shelf registration. See 17 C.F.R. $\$ 230.405$ (2011). Thus, companies with a relatively large public ownership still qualify as emerging growth companies and escape the Dodd-Frank Act's corporate governance provisions.

243 See S. 1933 (asserting the Bill's purpose is " $[t]$ o increase American job creation and economic growth"). 
IPO bubble in 2001.244 Many other factors better explain the decline in IPOs than any increase in regulatory costs after 2001.245

These deregulatory proposals chiefly demonstrate the continuing persistence of the Regulatory Sine Curve, even after a major crisis. In 2011, financial industry representatives formed an industry study group, the IPO Task Force, which quickly prepared a report attributing the decline in IPOs to regulatory and market structure changes. ${ }^{246}$ Entirely ignored by this report was the likely loss in investor confidence following the burst of the Internet stock bubble in 2000 or the Enron and WorldCom insolvencies in 2001-2002. The IPO Task Force proposed to remedy the decline in IPOs by dismantling many of the regulatory changes that were adopted following the 2001 market crash. ${ }^{247}$

244 One cannot deny that the number of IPOs declined significantly after 2000. This number appears to have peaked at 791 IPOs in 1996 and then fell to an average of 157 IPOs from 2001 to 2008, with a low of 45 IPOs in the financial crisis year of 2008. See IPO Task Force, Rebuilding the IPO On-Ramp: Puttinc Emerging Companies and the Job Market Back on the Road to Growth 6 (2011).

245 Industry groups cite costly regulation as a cause for the decline in IPOs, but SOX's Section 404(b) impact was not felt until 2004 when the PCAOB adopted Accounting Standard No. 2. See supra note 76 and accompanying text. Thus, during the 1990s when IPOs peaked, the legal environment was similar to that of the post-2000 decade when IPOs declined. To more fully understand the decline of IPOs, one must consider the following factors: (1) the loss of investor confidence in IPOs after the Internet bubble burst in 2000; (2) the impact of disclosures about serious conflicts of interest on the part of securities analysts after Eliot Spitzer and others exposed these conflicts; (3) the de-retailization of the market as individual investors are leaving the market and institutional investors are less dependent on sell-side analysts; (4) the loss of interest by institutional investors in smaller IPOs, which cannot provide investors with sufficient market depth to assure liquidity; and (5) the high, fixed costs of smaller IPOs, which make it cost efficient for smaller companies to raise capital in the private placement market. For a discussion of some of these factors, see Examining Investor Risks in Capital Raising: Hearing Before the Subcomm. on Sec., Ins., and Inv. of the S. Comm. On Banking, Hous. and Urban Affairs, 112th Cong. 20-23 (2011) (statement of John Coates, Professor of Law and Economics, Harvard Law School) (hereinafter Coates Hearing].

246 See IPO TASK FORCE, supra note 244, at 8 . For a more affirmative discussion of this report, see generally H.R. 3606, the Reopening of American Capital Markets to Emerging Growth Companies Act of 2011: Hearing Before the H. Subcomm. on Capital Mkts. and Gov't Sponsored Enters. of the H. Comm. on Fin. Servs., 112th Cong. (2011) (statement of Kate Mitchell, Managing Director at Scale Venture Partners). Mitchell's testimony identifies SOX Section 404(b) as the most costly barrier to becoming a public company, but does not identify any of the Dodd-Frank Act provisions as a significant barrier. See id. at 8-9. Still, if so, Mitchell's diagnosis hardly leads to a prescription of rolling back the Dodd-Frank Act.

247 In particular, the IPO Task Force would override the existing rules of FINRA and permit securities analysts associated with an underwriter who is participating in the offering to issue reports on the issuer at the time of the offering. See IPO Task Force, supra note 244, at 27-28. Today, FINRA Rule 2711 precludes a managing underwriter from distributing a research report about an issuer client until forty days after the registration statement becomes effective. See id. at 27 n.3. An industry self-regulatory body, not Congress, adopted this rule in response to the 2000-2002 controversy involving Internet securities analysts, most notably Henry Blodget and Jack Grubman, who became iconic examples of conflicted securities analysts as a result of enforcement actions undertaken by then New 
Time and again, this is the key move: to blame economic stagnation and job loss, not on a crash or a bubble, but on the regulation that follows it. The legislation proposed by the IPO Task Force has broad bipartisan support and seems certain to become law in 2012 as part of a job creation program. ${ }^{248}$ Although it will likely accomplish little in terms of reversing the decline in IPOs, this legislation will ease constraints imposed on the financial services industry. Above all, this episode shows again that, once a crisis passes, Congress can easily be persuaded to repeal legislation that it passed in response to the crisis. This proves not that the original legislation was flawed, but more that Congress can be manipulated, has a limited attention span, and will sometimes accept makeweight arguments, particularly in an election year. To be sure, in a national crisis, countervailing forces sometimes arise, but they do not remain organized and vigilant indefinitelyhence, the Regulatory Sine Curve persists.

\section{CONCLUSION}

The key and recurring debate over financial reform is between those who distrust both legislation and regulation (a position that the Tea Party Caucus exemplifies) and those who believe restraining systemic risk necessitates strong regulation. In this debate, the standard move of those who distrust regulation is to attribute economic stagnation and job loss to costly regulation, ignoring that the costs of market bubbles and crashes dwarf those of regulation. Their ability to do this is evidence of a collective social amnesia that overtakes Congress and others as soon as the crisis fades from the headlines. This recurrent amnesia is in turn evidence of what this Article has termed the Regulatory Sine Curve-a cycle driven by the differential in resources, organ-

York Attorney General Eliot Spitzer. See Jill I. Gross, Securities Analysts' Undisclosed Conflicts of Interest: Unfair Dealing or Securities Fraud?, 3 Colum. Bus. L. REv. 631, 635-46 (2002). Nonetheless, the IPO Task Force displays a collective amnesia about these conflicts, and Congress appears unable to resist the seductive argument that deregulation means job creation.

248 A number of bills are pending and seem likely to pass in 2012 that would enable small companies to avoid either or both of the registration requirements of the Securities Act of 1933 or the reporting requirements of the Securities Exchange Act of 1934. For detailed reviews of these bills, see generally Coates Hearing, supra note 245; Spurring Job Growth Through Capital Formation While Protecting Investors: Hearing Before the S. Comm. on Banking, Hous. and Urban Affairs, 112th Cong. (2011) (statement of John C. Coffee, Jr., Adolf A. Berle Professor of Law, Columbia University Law School). This Article does not contend that these bills undermine the federal securities laws, only that they show a recurrent pattern of congressional thinking that considers only the costs of regulation and not the cost of crashes and bubbles. Absent restored investor confidence or major technological breakthroughs, there is little prospect of an upsurge in the number of IPOs. 
ization, and lobbying capacity that favors those interests determined to resist further regulation. ${ }^{249}$

Without doubt, some regulation is foolish and overbroad, but, as this Article has emphasized, such overbroad regulation is usually repealed or curtailed relatively quickly, without the need for mandatory sunsets. The greater danger is that the forces of inertia will veto or block all change. The pervasive underregulation of "shadow banking," which continued for decades, was a leading cause of the 2008 financial debacle and the current economic stagnation. ${ }^{250}$ Failing meaningful implementation of the Dodd-Frank Act, financial executives may once again race like lemmings over the financial cliffs by taking on leverage that they cannot sustain. One cannot predict when this will occur, but driving this process will be the same perverse incentives: short-term executive compensation and market pressure for higher leverage and greater risk-taking. Equivocal regulation and bounded rationality will again aid and abet these root causes.

In short, history repeats itself, particularly when it is ignored. Worse yet, the Dodd-Frank Act faces potentially greater downsizing than SOX. This is because effective implementation of the DoddFrank Act requires greater regulatory encroachment into the core business decisions of financial institutions over their capital adequacy, leverage, and compensation. Thus, the Dodd-Frank Act seems destined to be resisted even more aggressively than SOX. If, however, a combination of equivocal rulemaking and legal challenges similarly neutralize the Dodd-Frank Act, the consequences may be far more ominous. Systemic risk poses a far greater threat to both the United States and the world's economy than did the corporate governance failures and accounting irregularities to which SOX responded.

It is not the contention of this Article that sustained reform is impossible or that, in response to a crisis, regulatory agencies are only capable of rearranging the deck chairs on the Titanic. That would overstate. Ideally, political entrepreneurs can unite and sustain a political coalition of investors, enabling them to resist better-funded special-interest groups. But those who took center stage over the last decade to play this role have had only a brief moment in the spotlight. ${ }^{251}$ In the absence of strong leadership, the first and reflexive

\footnotetext{
249 This disparity will only grow in the wake of Citizens United v. FEC, 130 S. Ct. 876, 886 (2010) (holding that the First Amendment protects corporations' and unions' independent expenditures in support of a political candidate from governmental limitations). For the finding that corporate political and lobbying expenditures are increasing in the wake of this decision, see Coates, supra note 46.

250 See Gorton \& Metrick, supra note 183, at 1-5.

251 As suggested, Eliot Spitzer and Andrew Cuomo have at times played the public entrepreneur role, but the SEC has been far more cautious and bureaucratic. See supra note 9 and accompanying text.
} 
response of many regulatory agencies after a crash is simply to move the Titanic's deck chairs around in a sufficiently noisy fashion to show that they are on the job or to justify increased bureaucratic power. Some evidence suggests that is again happening. ${ }^{252}$ Beyond this lack of imagination and political nerve, the greater problem is that financial regulators are often so closely intertwined with those that they regulate that they respond in an equivocal and even timid fashion. ${ }^{253}$ The recent joint rules on executive compensation adopted by the principal federal financial regulators exemplify this problem because the limited reach of these rules seems motivated more by a desire to protect the industry from competition than to control moral hazard. ${ }^{254}$

What could be done to compensate for the predictable tendency toward rapid erosion of reform legislation? One might advocate the use of stronger prophylactic rules in the original reform legislation with less delegation to administrative agencies. ${ }^{255}$ Indeed, had Congress known the degree to which the D.C. Circuit would broadly employ its own cost-benefit analysis to reject proposed agency rules of which that Court disapproved, Congress might have delegated less to the SEC and attempted to resolve issues legislatively on incomplete knowledge. Such a proposal for more prophylactic legislative rules would be the polar opposite of Professor Romano's mandatory sunset rule. Still, justifiable as such a shift might be, this Article stops short of recommending any across-the-board movement towards greater legislative specificity because it would entail undesirable rigidity. To be sure, legislative restrictions on judicial cost-benefit oversight of administrative agencies may be needed, particularly in this context. Another second-best substitute may be to use market-based reforms that em-

252 An excellent example is the SEC's latest release containing proposed credit-rating agency rules. See Nationally Recognized Statistical Rating Organizations, Exchange Act Release No. 64,514, 76 Fed. Reg. 33420 (proposed June 8, 2011). The release contains voluminous rules governing the training and supervision of credit-rating agency employees, but never recognizes that the underlying problem was not the credit-rating agencies' lack of competence, but conflicts of interest and pressure. See John C. Coffee, Jr., Ratings Reform: The Good, the Bad, and the Ugly, 1 HARv. Bus. L. Rev. 231, 236-44 (2011).

253 This may be because of the "revolving door" phenomenon, risk aversion about the political or reputational consequences of the agency suffering a litigation defeat, or budgetary constraints that limit the agency's ability to engage in aggressive enforcement. See Sorkin, supra note 38. This author makes no attempt to disentangle the various causes. Finally, the regulator may trim its sails and propose only equivocal rules in fear of judicial rejection of proposed rules.

254 See supra notes 217-25 and accompanying text.

255 The Securities Exchange Act of 1934 does contain several such prophylactic rules, for example, Section 16(b) of that Act broadly prohibits "short swing" trading without any need to prove scienter or the possession of material information. See ch. 404, 48 Stat. 881 (codified as amended at 15 U.S.C. $\$ 78$ p (2006)). The Public Utility Holding Company Act of 1935's infamous "death sentence" for holding companies would be another example. See supra note 23. 
ploy more objective market tests and thus depend less on administrative implementation. ${ }^{256}$ Although disclosure is always a useful remedy, it needs to refocus on weak or equivocal administrative implementation. Some courts may also embarrass the SEC into stronger enforcement action. ${ }^{257}$ It remains premature, however, to evaluate these options until the implementation of the Dodd-Frank Act is further along.

Capture is an overused and underdefined term. This Article does not assert that financial regulators have been captured, but does conclude that they are far better at prosecuting outliers and crooks than in controlling reckless ambition by those at the top of the corporate hierarchy. In all likelihood, some desirable reforms will emerge from the Dodd-Frank Act that will reduce the risk, at least marginally, of another systemic risk crisis for the immediate future. Predictably, capital adequacy standards will be raised and leverage ratios marginally restricted at TBTF institutions. But the pursuit of higher leverage has not yet been checked. The acid test for meaningful reform is likely to lie in the outcomes in three areas: (1) the implementation of the Volcker Rule, ${ }^{258}$ (2) the fate of the Dodd-Frank Act's preference for trading OTC derivatives through exchanges and clearinghouses, ${ }^{259}$ and (3) the strength of the capital adequacy rules for TBTF banks. ${ }^{260}$ In each case, the exceptions may overwhelm the rule.

256 For such a proposal, see Coffee, supra note 124, at 822-23, 828-46.

257 See supra note 119 and accompanying text (discussing Judge Rakoff's refusal to accept proposed SEC settlements).

258 Two experienced Davis Polk \& Wardwell LLP attorneys, one a former SEC Commissioner, recently predicted that financial regulators would be both forced to withdraw their 298-page Volcker Rule proposal and start over in reproposing the rule. See Annette $\mathbf{L}$. Nazareth \& Gabriel D. Rosenberg, Comment: 12 Regulatory Reform Predictions for '12, FiN. Times (Dec. 23, 2011, 11:12 AM), http://www.ft.com/intl/cms/s/0/e6fc8ce4-2d4a-11elb985-00144feabdc0.html\#axzzlpUDmsPEj. If this happens, a significantly weaker rule will likely follow. See supra notes 235-38 and accompanying text.

259 The New York Times has recently editorialized that the Obama Administration has delayed too long, and deferred to "absurd arguments," in requiring OTC derivatives to be traded in an "open exchange." This editorial further called on President Obama "to provide full-throated support for implementing and enforcing Dodd-Frank Rules. Otherwise the law will be a reform in name only." Editorial, A Long Road to Regulating Derivatives, N.Y. TIMEs, Mar. 25, 2012, at SR12. Nonetheless, the industry continues to resist, including by demanding that the Dodd-Frank Act's swap-trading rules not apply extraterritorially. See Alexandra Alper, Banks Air Fears Over Scope of U.S. Swaps Rules, ReUTERS (Feb. 8, 2012, 5:29 PM), http://www.reuters.com/article/2012/02/08/financial-regulation-swapsidUSL2E8D8FHN20120208 (noting that U.S. and foreign banks are pressing the CFTC and the SEC not to impose these rules on U.S. banks offshore, arguing that it will destroy the U.S. banks' international competitiveness).

260 The Federal Reserve announced relatively tough capital adequacy rules, but none more stringent than those required by Basel III. The New York Times described the proposal as "a small victory for banks." See Edward Wyatt, Fed Unveils Plan to Limit Chance of a Banking Crisis, N.Y. TImes, Dec. 21, 2011, at B1. 
Across most of the financial regulatory agencies, the deep-seated preference is to depend upon bureaucratic oversight and case-by-case monitoring in preference to more prophylactic rules. But, as prior market crashes show, the same cognitive limitations that blind market participants also cloud the vision of regulators. More objective, market-based tests are possible and desirable, ${ }^{261}$ but they have no supportive constituency. As a result, the same regulators who missed the Long-Term Capital Management crisis in 1998, the IPO Bubble in 2000, the Enron and WorldCom failures in 2001-2002, the market timing scandal involving mutual funds in 2004, Bernie Madoff and the Lehman and AIG collapses in 2008 seem likely in time to do it again in the future. Sadly, the inevitability of bounded rationality, compounded by the Regulatory Sine Curve, implies that eventually we will face another systemic risk crisis.

It is still too soon to say that the 2008 crisis was wasted, but it has not been exploited. Rather, the equivocal response to date implies that the Dodd-Frank Act's reforms will be marginalized over time.

261 For a discussion of possible market-based tests that could supplement regulatory oversight, see Coffee, supra note 124 , at 828-46. 